\title{
Analysis of operative factors and practices in social CRM
}

\author{
Ayush Tiwari* and Madhvendra Misra \\ Department of Management Studies, \\ Indian Institute of Information Technology Allahabad, \\ Allahabad 211015, Uttar Pradesh, India \\ Email: ayush0312@gmail.com \\ Email: madhvendra@iiita.ac.in \\ *Corresponding author
}

\begin{abstract}
In today's world, the culmination of CRM and social media provides a huge platform for handling and networking with the customers. Organisations nowadays are training their workforce in social CRM technologies. There are immense opportunities and huge scope for marketers in the field of social CRM. Social media extends its powerful impact on the core areas of CRM and hence can be used as a very powerful weapon for the organisations. The purpose of this research paper is to study the impact of operative factors in social CRM domain on the performance measures of the organisation. The study aims to discover and assess the implications of social CRM on the organisation's performance behaviour. The performance measures are identified in the light of social CRM domain. The identified operative factors such as customer focus, competitor focus, marketing intelligence and cross-functional collaboration are the factors that play a pivotal role in determining the performance of the organisation.
\end{abstract}

Keywords: customer relationship management; social CRM; social media; marketing intelligence; performance measures.

Reference to this paper should be made as follows: Tiwari, A. and Misra, M. (2018) 'Analysis of operative factors and practices in social CRM', Int. J. Digital Enterprise Technology, Vol. 1, Nos. 1/2, pp.135-176.

Biographical notes: Ayush Tiwari is a final year MBA student at the Indian Institute of Information Technology Allahabad, India. He is pursuing his MBA in Marketing and Information Technology. He has completed his Bachelor's of Engineering from the Technocrats Institute of Technology, Rajiv Gandhi Proudyogiki Vishwavidyalaya, Bhopal in 2012. His research interest includes strategic management, marketing, information technology, digital marketing and process management and consultancy.

Madhvendra Misra is presently working as an Associate Professor at the Indian Institute of Information Technology Allahabad, India. He has more than 16 years of experience in the field of management education. For the last 12 years, he has been a faculty member at the Department of Management Studies at IIIT-Allahabad. His research interest includes marketing, strategy and technology forecasting, process management and business process re-engineering, consultancy, information strategy and digital marketing. He has published various papers in reputed journals and has contributed in several books. 


\section{Introduction}

Customer relationship management is termed as a process which assists in identifying potential customers, recognising their needs and creating relationships with them by giving them preferable products and improved customer service (Patil, 2015).Customer relationship management can also be said to as customer centred, i.e., across all the information that has the relationship with the consumer, he is put at the centre and only accredited people inside the organisation are having permission to access the information (Patil, 2015). It not only increases the transaction volume from customers but also provides a competitive edge in today's market. In order to handle customers electronically, business environment in today's world is exceedingly changing and it is experiencing speedy changes as a result of improvements in technology, increased demands and awareness.

Social media can be defined as creation, utilisation and transfer of information over different platforms which are available for social interaction. Social media is a culmination of Internet-based applications that build on technological and intellectual foundations of Web 2.0 and which also allow users to generate and transfer their content (Palmatier et al., 2006).

The consolidation of CRM with social media generates a huge scope to cultivate interactions among customers. It also provides businesses a path to handle and monitor use of social networking so as to engage customers on social media platforms.

Facebook, LinkedIn and blogs are used for gathering data to integrate it into the sales cycle of organisations (Rodriguez et al., 2014). For the past two years, tools and technologies used in social CRM have increased substantially after analysing its immense capabilities (Trainor et al., 2014). Building a stronger relationship with the customers is the need of the hour and these social media technologies have enabled marketing managers to leverage the existing CRM capabilities with the nascent technologies (Trainor et al., 2014). A focused approach towards maintaining relationships with customers is enhanced with the help of social CRM.

In this ever-evolving age of technology, social CRM directs organisation a proper way in building effective relationships with customers. These emerging social media technologies along with activities oriented towards customers collaboratively work together in social CRM. Customer centricity is the essence of social CRM. Existing processes of sales, marketing and after-sales services are now aligning their ways towards social media. The new emerging technologies are the sole drivers in Social CRM. Anticipating the immense scope and opportunities in social CRM domain, organisations are making their workforce trained to excel in social CRM technologies and are doing massive investments in this field. Social media and CRM are viewed as two diverse yet holistic dimensions of social CRM.

As traditional CRM has its three basic components as customer acquisition, customer retention and termination, imbibing social media technologies in all the three components will give the organisation an edge over its competitors (Malthouse et al., 2013). The engagement through social media impacts the core areas of CRM as well as aiding various business areas such as performance evaluation, human resources, information technology and overall marketing strategy (Malthouse et al., 2013).

It would be of paramount interest for organisations to evaluate and assess the performance of the organisation after adequate placement of social CRM activities. The subject matter as explored and evaluated provides sufficient material for constructing 
adequate research paradigm evaluating the performance of the organisation after imbibing the social media facet into the traditional CRM practices.

\section{Literature review}

Analysis of secondary and tertiary academic and industry resources is performed that builds knowledge on different approaches to customer relationship management. A rigorous literature review around the topic of social CRM is done and yielded the following theoretical background in a sequential manner.

Social media is made up of two related concepts, i.e., Web 2.0 and user-generated content. It consists of online applications that utilise the advancements of the internet and allow users in the generation of the content (Kaplan and Haenlein, 2010). Social media is impacting the relationships of businesses with their customers. It provides privilege and power to the customers to interact with the organisation (Charron et al., 2006). Content over social media is being constantly created irrespective of businesses getting involved in it (Woodcock et al., 2011).

Customer relationship management is a business strategy which utilises the concept of relationship marketing to harness long-term, profitable relationships with customers and stakeholders (Payne and Frow, 2005). Coupling of social media capabilities and initiatives in customer relationship management domain has led to the emerging concept of social CRM. Social CRM in a more holistic way, as a strategic approach enabled by technology, infrastructure and social media capabilities so as to increase the engagement of customer in creating mutually beneficial value (Greenberg, 2010).

A comparison between traditional CRM and Social CRM has been done and found that customer relationship management has been technology enabled with the help of various social media platforms, where customers interact with businesses via social media platforms instead of interacting with traditional CRM channels like bricks and mortar locations, call centres and organisation's website (Baird and Parasnis, 2011). Social CRM enables an organisation with more of customer data and smoothens the interaction between the two effectively and efficiently (Woodcock, 2011). The paradigm shift from CRM to social CRM has been in the issue of control. In CRM, the control lies in making the relationship with customers whereas, in social CRM, it has been shifted to the customer (Greenberg, 2010). Managing interactions and communications with customer become the centre point instead of focusing only on the customer (Baird and Parasnis, 2011; Sarner, 2012). Failure of CRM is in developing in-depth insights and information about customers. Traditional CRM was generating data that can only be transacted but in social CRM, in addition to this transactional data, behavioural and emotional insights about customers are also provided. In earlier CRM model, customer's opinion was being formed by the organisation but in social CRM model, the customer is viewed as an individual or a partner who contributes his cooperation in forming the opinion about products and services (Greenberg, 2009). With the enormous increase in the socially active customer base, statistical analysis of customers' demands is the need of the hour. Earlier, the existing customer relationship management practices focus more on the recentness, recurrence and budgetary parameters. But large-scale data generated from social media requires a time series statistical methodology to assess different aspects of customers (Song et al., 2017). 
Applications of social CRM can be implemented across organisations in following functions: business intelligence, relationship management, marketing (Collective Intellect, 2010). Relationship management further includes sales, customer service and marketing further includes analysis, market research and branding. These social CRM applications are mainly used for bridging the gap between CRM systems and social media [Reinhold and Alt, (2012b), p.158]. To increase the profitability of an organisation, social CRM applications provide the opportunities like building customer trust, gaining insights, improving selling, up-selling or cross-selling, gaining word of mouth, differentiating products and services, lowering service cost and improving the experience of customer [Sarner, (2012), p.1]. In the process of incorporating social media dynamics and perspectives into the existing customer relationship management practices, valuable customer experience is also co-created. Efficient social CRM proficiency led to enhanced customer experience which ultimately led to improved firm performance (Kamboj et al., 2016). The influence of social CRM strategies has not left any kind of organisation untouched with its ubiquitous impact. Social media skills integrated with relationship management strategies in the green retailers' domain also exhibited the successful retention of customers through information and service content being delivered social media platforms of the green brands (Kang and Kim, 2017).

A model is being suggested for improving and managing the organisation performance while focusing on customer's need and collecting relevant information about them (Kohli and Jarowski, 1990). Market orientation is a term coined by them for analysing organisational performance. The organisations which strive to achieve competitive advantage in their domains needs market orientation which will provide customers with the worth they value and hence help organisations in achieving competitive advantage. Many researchers over the period of time have developed market orientation models and the elements which were found to play a crucial role in the model were customer focus, competitor focus, market intelligence generation and inter-functional coordination (Narver et al., 1998). These elements are identified as the operative factors.

The value propositions which were provided through social CRM are along the similar lines to that offered by elements of market orientation The value propositions which are offered by social CRM are providing opportunity for collaboration and information sharing, generating market intelligence and deepening customer focus with the help of Social CRM tools in service, sales and customer relationship management (Wang and Owyang, 2010; Greenberg, 2009 and Matz, 2011).

The first element of the market orientation model or the operative factor is customer focus. Social CRM tools deepens the insights about social customer and keeps constant monitoring and aligning existing customers with potential ones (Wang and Owyang, 2010). The tools used in Social CRM focus on generating knowledge and customer-centric information Organisations to achieve innovatively competitive advantage and creating customer value, they must be using social media monitoring tools to identify and uncover various marketing opportunities related to customer needs (Wagner and Hughes, 2010). Scanning customer data through social media using Social CRM tools can extract or mine relevant insights about customers and can enable innovation and growth of organisation [Reinhold and Alt, (2012a), p.158]. Response through social marketing, tracking the social campaign and event management in social domain are some of the activities that organisations can use to generate valuable insights about customers and intelligence reports with the help of social CRM tools (Wang and 
Owyang, 2010). These tools are made to actively engage the conversations of their customers in social domain and hence empower the organisation in generating market intelligence (Metz, 2011). Social CRM applications used are radian-six which is used in the analysis of social network and monitoring of social media and jive and lithium which is used for hosting online platforms (Sarner et al., 2010).

Social CRM also provides great insights into the customer domain of organisation thus making it easier and faster to disseminate information within the organisation (Wang and Owyang, 2010; Metz, 2011). There can be two dimensions within which customer focus can be studied. They are social sales and social care.

The organisations that to keep ahead in the market, they need to anticipate the needs and demands of customers and this anticipation can be facilitated with the help of tools using social CRM (Kohli and Jarowski, 1990). These tools are called as social Sales tools. These tools are used not only for closing the sales rather it is employed to bring potential customers into the sales process (Metz, 2011). These social selling tools are ahead of the traditional sales processes in identifying the urgent issues and concerns with which the customers are dealing and identifying places where these social customers are spending most of their time (Wagner and Hughes, 2010; Metz, 2011). Thus they get into those crucial insights ahead of CRM channels followed traditionally. This tool increases the sales function of the organisation tremendously (Greenberg, 2010). Some of the social sales tools like: Salesforce.com, Oracle Social CRM tools and Radian six (Sarner et al., 2010).

Extension of CRM channels used for service/support traditionally with the emerging social media channels would be a leveraging factor for the organisation in delivering its customers need and satisfaction (Narver and Slater, 1990; Kohli and Jarowski, 1990; Deng and Dart, 1994). Nowadays users on social media platforms and customers prefer brands which are engaged in customer care services on social media platforms. These social media users got irritated by company phone calls for dealing customer care services and would like to get entertained by social care methods (Nielsen,2012). Issues, concerns and complaints can be dealt more effectively using social media tools (Greenberg, 2010). Radiansix and Jive and Lithium are some of the applications that are used in social care (Sarner et al., 2010).

The second element of market orientation model discusses marketing intelligence, which is the second operative factor. Scanning customer data through social media using social CRM tools can extract or mine relevant insights about customers and can enable innovation and growth of organisation [Reinhold and Alt, (2012a), p.158]. Response through social marketing, tracking the social campaign and event management in social domain are some of the activities that organisations can use to generate valuable insights about customers and intelligence reports with the help of social CRM tools (Wang and Owyang, 2010). These tools are made to actively engage their customers in social domain and hence empower the organisation in generating market intelligence (Metz, 2011).

The third operative factor is cross-functional collaboration. Dynamism and responsiveness are the two main capabilities that an organisation should possess to stay ahead in the market. The information and insights about customers that these Social CRM tools are able to extract should be circulated and propagated across all functions and domains of the organisation (Kohli and Jarowski, 1990). Collaboration, cooperation and coordination among various functions of the organisation would ultimately provide customer value (Narver and Slater, 1990). Knowledge sharing and information 
dissemination coupled with participation and teamwork of various functions in the organisation helps an organisation achieve its goal of becoming more focused on customer domain (WoodCock et al., 2011).

From an academic as well as the industrial perspective it is of utmost importance to evaluate the performance of Social CRM tools and practices employed in the organisations. Social CRM performance measures are very crucial in monitoring and profiling the success and growth of the organisation (Baird and Parasnis, 2011). The existence of a performance measurement model is essential for every organisation (Sarner et al., 2011). A social CRM performance model is developed combining social CRM performance metrics along with traditional CRM metrics which include customer lifetime value, brand awareness, competitive advantage, financial benefits, new product performance, customer interaction and orientation from the social media perspective (Küpper et al. 2014)

The above-listed parameters constitute the performance measurement of the organisation.

The organisations are sensing the necessity and the benefits that would come across in the post-transition phase of Social CRM implementation. Customer acquisition, retention and loyalty are the main pillars of the organisation that are concretely build using social CRM practices and that ultimately result in the enhanced profitability of the organisation (Elena, 2016). Social media enables the organisations to become more customer-oriented and market driven (Ananda et al., 2016). The merging of customer relationship management with social media programs is facilitating the collaborative dialogues and social experiences and is being highly valued by customers. This is the real essence of social CRM (Baird and Parasnis, 2011). The organisations should leverage the social space to engage their customers actively and bringing out a significant return on minimum investments in efforts through social media (Roggeveen and Grewal, 2016). The existing customer relationship management techniques and strategies are taking a new and revolutionary birth that enables marketers to relate to customers in a more specified and better way (Zahoor et al., 2016).

The existing practices of customer relationship management have been questioned considering the rapid emergence of social media practices and usage in this field. From the perspective of small and medium enterprises, the implementation the of social CRM practices significantly improves the decision-making capability of executives by identifying the crucial predictors of social CRM (Ahani et al., 2017). The entrepreneurs operating in microenterprises also explores the dynamics of Social CRM practices and report higher business performance and satisfaction. Entrepreneurs having less interpersonal skills and are socially less competent, can improve their customers' satisfaction using social CRM (Charoensukmongkol and Sasatanun, 2017).

The application of social media practices has gained so much importance in today's socially evolving world that it has now become imperative for any organisation to mould their existing marketing approach and inculcate dynamic social media capabilities to enhance customer benefits and satisfaction, thus improving organisations' performance (Wang and Kim, 2017). Social media and various social CRM practices have also significantly increased behavioural traits of the salesperson. The sales oriented social CRM practices has directly impacted their service behaviour in terms of enhanced perseverance, improved compassion and increased sincerity (Agnihotri et al., 2017). 
Table 1 Literature matrix

\begin{tabular}{|c|c|c|}
\hline Variable & Definition & Author/report \\
\hline \multirow[t]{3}{*}{ Social media } & $\begin{array}{l}\text { Social media is a culmination of internet based } \\
\text { applications that build on technological and } \\
\text { intellectual foundations of Web } 2.0 \text {, which also } \\
\text { allow users to generate and transfer their content } \\
\text { as well }\end{array}$ & Palmatier et al. (2006) \\
\hline & $\begin{array}{c}\text { Provides privilege and power to the customers to } \\
\text { interact with organisation }\end{array}$ & Charron et al. (2006) \\
\hline & $\begin{array}{l}\text { Social media is made up of two related concepts, } \\
\text { i.e., Web } 2.0 \text { and user generated content. }\end{array}$ & $\begin{array}{l}\text { Kaplan and Haenlein } \\
(2010)\end{array}$ \\
\hline $\begin{array}{l}\text { customer } \\
\text { relationship } \\
\text { management }\end{array}$ & $\begin{array}{c}\text { Customer relationship management is a business } \\
\text { strategy which utilises the concept of } \\
\text { relationship marketing to harness long term, } \\
\text { profitable relationships with customers and } \\
\text { stakeholders }\end{array}$ & Payne and Frow (2005) \\
\hline \multirow[t]{2}{*}{ Social CRM } & $\begin{array}{l}\text { A paradigm that can provide next-generation } \\
\text { personalised customer engagement experience } \\
\text { by bringing real- time sense of customer } \\
\text { centricity and by harnessing the power of social } \\
\text { network economy }\end{array}$ & $\begin{array}{l}\text { Shyamalee and Srinath } \\
(2010, \text { p.2) }\end{array}$ \\
\hline & $\begin{array}{c}\text { Social CRM in a more holistic way as a strategic } \\
\text { approach enabled by technology, infrastructure } \\
\text { and social media capabilities so as to increase the } \\
\text { engagement of customer in creating mutual } \\
\text { beneficial value }\end{array}$ & Greenberg (2010) \\
\hline $\begin{array}{l}\text { Customer } \\
\text { focus }\end{array}$ & $\begin{array}{l}\text { Social CRM provides great insights into the } \\
\text { customer domain of organisation thus making it } \\
\text { easier and faster to disseminate information } \\
\text { within the organisation }\end{array}$ & $\begin{array}{l}\text { Wang and Owyang (2010) } \\
\text { and Metz (2011) }\end{array}$ \\
\hline \multirow[t]{2}{*}{ Social sales } & $\begin{array}{l}\text { Anticipation of needs and demands of customers } \\
\text { is facilitated through social sales tools. }\end{array}$ & $\begin{array}{l}\text { Kohli and Jarowski (1990) } \\
\text { and Metz (2011) }\end{array}$ \\
\hline & $\begin{array}{c}\text { Some of the social sales tools are } \\
\text { Salesforce.com, Oracle Social CRM tools and } \\
\text { Radian } 6\end{array}$ & Sarner (2010) \\
\hline \multirow[t]{2}{*}{ Social care } & $\begin{array}{c}\text { Tools that are used for customer service and } \\
\text { support activities }\end{array}$ & $\begin{array}{l}\text { Narver and Slater (1990), } \\
\text { Kohli and Jarowski (1990) } \\
\text { and Deng and Dart (1994) }\end{array}$ \\
\hline & $\begin{array}{l}\text { Radiansix and Jive and Lithium are some of the } \\
\text { applications that are used in social care }\end{array}$ & Warner (2010) \\
\hline $\begin{array}{l}\text { Marketing } \\
\text { intelligence }\end{array}$ & $\begin{array}{l}\text { Scanning customer data through social media } \\
\text { using Social CRM tools can extract or mine } \\
\text { relevant insights about customers and can enable } \\
\text { innovation and growth of organisation }\end{array}$ & $\begin{array}{l}\text { Reinhold and Alt } \\
(2012, \text { p.158) }\end{array}$ \\
\hline
\end{tabular}


Table 1 Literature matrix (continued)

\begin{tabular}{|c|c|c|}
\hline Variable & Definition & Author/report \\
\hline \multirow[t]{3}{*}{$\begin{array}{l}\text { Cross } \\
\text { functional } \\
\text { collaboration }\end{array}$} & $\begin{array}{l}\text { Circulation and propagation of customer's } \\
\text { information and insights across all functions and } \\
\text { domains of organisation }\end{array}$ & Kohli and Jarowski (1990) \\
\hline & $\begin{array}{l}\text { Collaboration, cooperation and coordination } \\
\text { among various functions of the organisation } \\
\text { would ultimately provide customer value }\end{array}$ & Narver and Slater (1990) \\
\hline & $\begin{array}{c}\text { Knowledge sharing and information } \\
\text { dissemination coupled with participation and } \\
\text { teamwork of various functions in the } \\
\text { organisation }\end{array}$ & Woodcock et al. (2011) \\
\hline $\begin{array}{l}\text { Social CRM } \\
\text { performance } \\
\text { measures }\end{array}$ & $\begin{array}{l}\text { A social CRM performance model combining } \\
\text { social CRM performance metrics along with } \\
\text { traditional CRM metrics which includes } \\
\text { customer lifetime value brand awareness, } \\
\text { competitive advantage, financial benefits, new } \\
\text { product performance and customer interaction } \\
\text { and orientation from social media perspective }\end{array}$ & Küpper et al. (2014) \\
\hline
\end{tabular}

Social CRM techniques and strategies have also opened new avenues of delivering better customer services and elaborate marketing communications among customers. These methods and practices have significantly reduced the costs incurred in marketing activities. Socially active customers can communicate directly with e-tailers such as snapdeal with an idea of collaboration and give valuable feedback to the e-commerce companies. These socially driven practices improve and increase every aspects and milestone of customer relationship management lifecycle (Kulkarni and Gnanpragash, 2017). The buzz around social CRM has led companies to revamp their communication strategies, develop active engagement with their customers and subsequently devise the strategy around social CRM techniques. The organisations have realised the importance of social CRM as an excellent method for getting expensive real-time customer data in a cost-effective manner (Paliouras and Siakas, 2017).

The study analyses the major operative factors and practices in social CRM and its considerable impact on performance measures of the organisation. As the previous researchers (Kohli and Jarowski, 1990; Narver et al., 1998) states that the market orientation model constitutes of four major operative factors, this study aims to analyse those identified operative factors in the social CRM space. The four major operative factors in traditional CRM domain are identified as customer focus, competitor focus, marketing intelligence and cross-functional collaboration (Narver et al., 1998). These four factors have been playing a crucial role in traditional CRM practices. The study analyses the interplay of these factors in Social CRM domain. The study also aims to examine the impact of these four operative factors being conducted in social media domain on the performance measurement of the organisation. Thus the research model, which is exhibiting the main hypothesis (Hypothesis 4) of the study, is being derived as follows.

The present paper examines the following hypothesis:

Hypothesis 1 There is a positive relationship between use of social CRM and the operative factors. 
Hypothesis 2 There is a positive relationship between social CRM duration and operative factors.

Hypothesis 3 There is a significant relationship between the operative factors and the number of functions for which social CRM is used.

Hypothesis 4 There is a significant impact of operative factors on social CRM performance measures.

Hypothesis 5 There is significant variation regarding social CRM duration between $\mathrm{B} 2 \mathrm{~B}$ and $\mathrm{B} 2 \mathrm{C}$ market type.

Figure 1 Research model (see online version for colours)

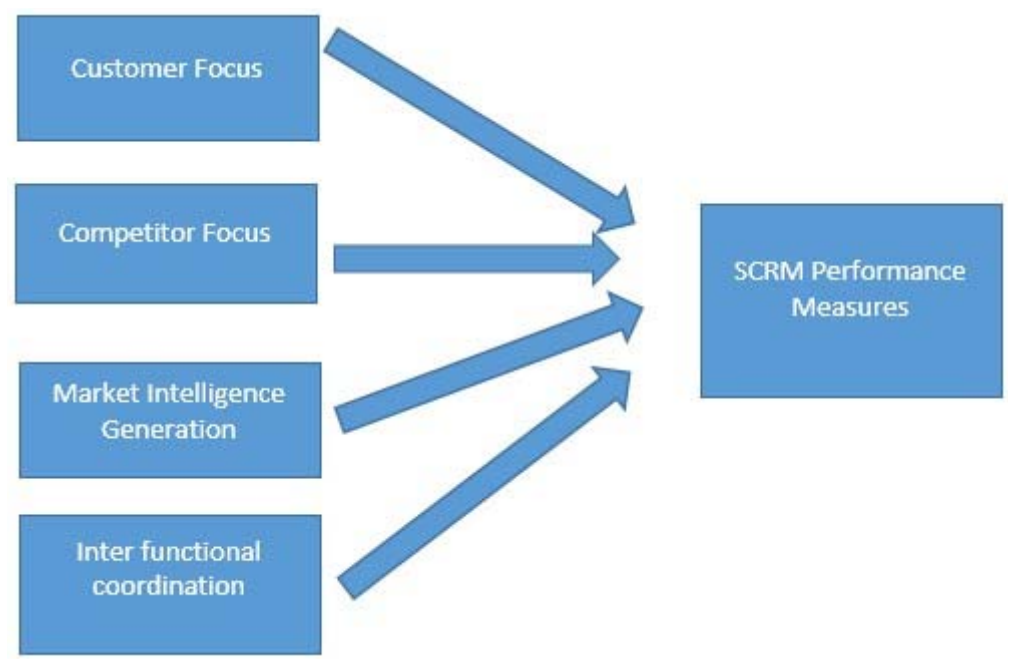

\section{Research methodology}

\subsection{Data collection}

The primary data need for the study is collected with the help of a survey. The survey is conducted with the help of a questionnaire which is one of the research instruments being used by researchers. The sampling frame considered in the research consists of various working professionals and executives working in different industries. Various social media platforms such as Facebook and LinkedIn are used for data collection purpose. A considerable sample size of 95 respondents is taken into account

\subsection{Measures}

The questionnaire consists of various demographic factors including market type, size of an organisation, industry in which the organisation is operating. It also consists of questions social media platforms being used by the organisations. Also, it tries to examine the role played by the respondents both individually as well as in the light of social CRM practices. 
To examine the impact of various operative factors enabled with the help of social media, the measuring construct which is being used in this research is a five-point Likert scale. Strongly agree is attributed with number 5 and strongly disagree is attributed with number 1. The intermediate scale ranking is ordered sequentially. Though the data collected is ordinal in nature but still, parametric tests can be used to analyse the data on the basis of normality distribution. When the sample size is greater than 100, the normality distribution about the population is met and hence parametric tests can be employed for data analysis

\section{Data analysis}

\subsection{Demographic statistics}

The data collected shows the explicit picture of demographical information about the organisations participating in the survey. There are 19 types of respondents' industries. The largest number of respondents are from information technology $68(71.57 \%)$ followed by banking 4 (4.21\%) and rest are others.

Table 2 Type of industries

\begin{tabular}{lcc}
\hline Industry & Frequency count & Percentage \\
\hline Information technology & 68 & 71.57 \\
Banking & 4 & 4.21 \\
Hospitality & 1 & 1.05 \\
Telecommunication & 2 & 2.1 \\
Manufacturing/construction & 2 & 2.1 \\
Education & 2 & 2.1 \\
Tourism & 1 & 1.05 \\
Medical device & 1 & 1.05 \\
Labour welfare & 1 & 1.05 \\
Agriculture & 1 & 1.05 \\
Civil aviation & 1 & 1.05 \\
Power & 1 & 1.05 \\
Seeds grading industry & 1 & 1.05 \\
FMCG & 1 & 1.05 \\
Insurance & 1 & 1.05 \\
Finance and investments. & 1 & 1.05 \\
Clinic & 1 & 1.05 \\
Industrial automation & 1 & 1.05 \\
Market research & 1 & 1.05 \\
Others & 3 & 3.15 \\
\hline
\end{tabular}

Size of an organisation is another dimension of descriptive statistics. Majority of the organisations are having more than 5,000 employees. 
Table 3 Size of organisation

\begin{tabular}{lcc}
\hline Size of organisation & Frequency count & Percentage \\
\hline Up to 200 employees & 9 & 9.47 \\
$201-500$ employees & 6 & 6.31 \\
$501-1,000$ employees & 5 & 5.26 \\
$1,001-5,000$ employees & 24 & 25.26 \\
Above 5,000 employees & 51 & 53.68 \\
\hline
\end{tabular}

Information about market type is also crucial in gaining an overall understanding of the organisation.

Table 4 Type of markets

\begin{tabular}{lcc}
\hline Market & Frequency & Percentage \\
\hline B2B & 61 & 64.21 \\
B2C & 34 & 35.79 \\
\hline
\end{tabular}

Social footprints of the organisations are a clear indicator of the importance of social media usage in the organisation. Table 5 examines this very fact.

Figure 2 Various social media platforms used by organisations (see online version for colours)

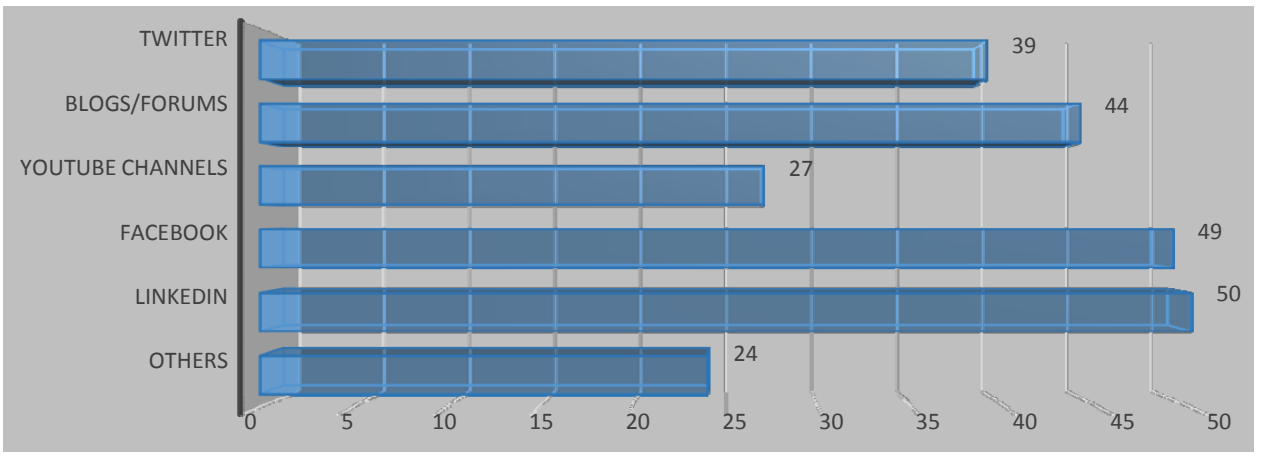

Table 5 Seniority level of employees

\begin{tabular}{lcc}
\hline Seniority level & Frequency & Percentage \\
\hline Manager & 33 & 34.73 \\
Executive & 23 & 24.21 \\
Senior & 16 & 16.84 \\
Junior & 9 & 9.47 \\
Director & 6 & 6.32 \\
Head of office & 2 & 2.11 \\
Other & 6 & 6.32 \\
\hline
\end{tabular}


To assess the respondents' information, it is necessary to acquire knowledge about their seniority level in the organisation. Majority of the respondents are working at manager level followed by the executive. Table 5 shows the same.

Apart from the seniority level, information about the functions that the respondents are performing is also important.

Table 6 Functions performed by respondents

\begin{tabular}{lcc}
\hline Functions (performed by respondents) & Frequency & Percentage \\
\hline Customer relations & 28 & 29.5 \\
Sales & 24 & 25.3 \\
Marketing & 25 & 26.3 \\
Market research & 12 & 12.6 \\
Others & 48 & 50.5 \\
\hline
\end{tabular}

Figure 3 Functions performed by respondents (see online version for colours)

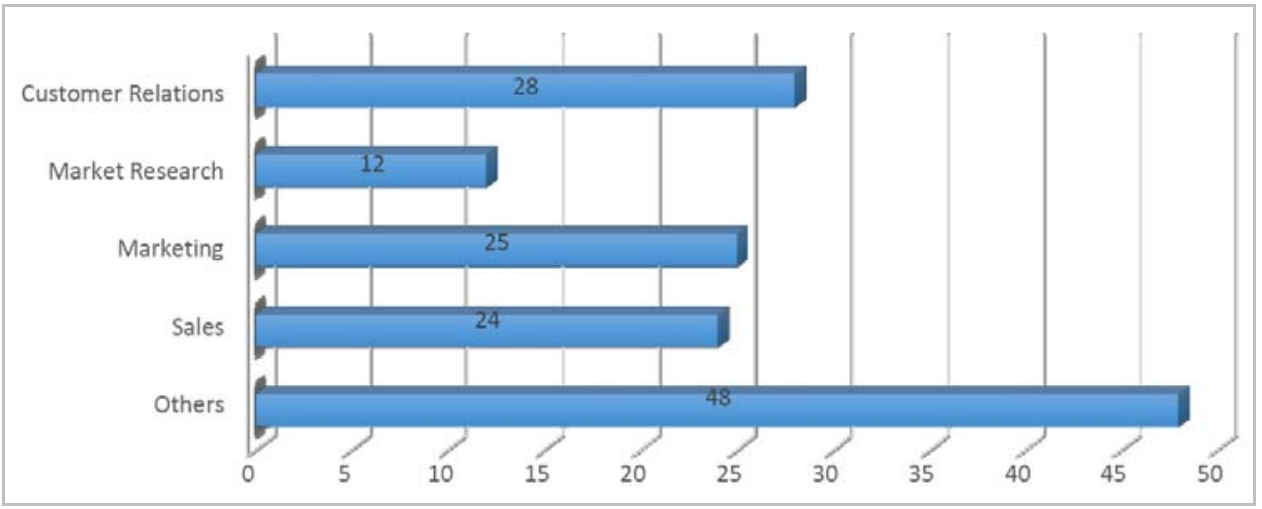

To assess the overall impact of social CRM on organisation performance, it is necessary to have an insight about the duration for which social CRM is being used in the organisation.

Table 7 Duration of social CRM usage in organisations

\begin{tabular}{lcc}
\hline Social CRM duration & Frequency & Percentage \\
\hline Up to 6 months & 17 & 17.89 \\
6-12 months & 11 & 11.57 \\
$12-18$ months & 12 & 12.63 \\
$18-24$ months & 2 & 2.1 \\
Above 24 months & 53 & 55.78 \\
\hline
\end{tabular}

To explore the dependency between organisation size and social CRM usage duration, cross tabulation method is the prominent one. Following table of cross-tabulation between duration of social CRM usage and organisation size shows that $34(35.78 \%)$ respondents of organisations having more than 5,000 employees are using social CRM for more than two years. 
Table 8 Cross tabulation of organisation size and duration of social CRM

\begin{tabular}{|c|c|c|c|c|c|c|c|}
\hline & & \multicolumn{5}{|c|}{ Social CRM_duration } & \multirow[b]{2}{*}{ Total } \\
\hline & & $\begin{array}{l}12 \text { to } 18 \\
\text { months }\end{array}$ & $\begin{array}{l}18 \text { to } 24 \\
\text { months }\end{array}$ & $\begin{array}{l}6 \text { to } 12 \\
\text { months }\end{array}$ & $\begin{array}{l}\text { Over } 24 \\
\text { months }\end{array}$ & $\begin{array}{l}\text { Upto } 6 \\
\text { months }\end{array}$ & \\
\hline \multirow[t]{5}{*}{$\begin{array}{l}\text { Organisation } \\
\text { size }\end{array}$} & $\begin{array}{c}1,001 \text { to } \\
5,000 \\
\text { employees }\end{array}$ & 7 & 1 & 2 & 11 & 3 & 24 \\
\hline & $\begin{array}{l}201 \text { to } 500 \\
\text { employees }\end{array}$ & 1 & 0 & 0 & 3 & 2 & 6 \\
\hline & $\begin{array}{c}501 \text { to } \\
1,000 \\
\text { employees }\end{array}$ & 2 & 0 & 0 & 0 & 3 & 5 \\
\hline & $\begin{array}{c}\text { Above } \\
5,000 \\
\text { employees }\end{array}$ & 2 & 0 & 7 & 34 & 8 & 51 \\
\hline & $\begin{array}{l}\text { Upto } 200 \\
\text { employees }\end{array}$ & 0 & 1 & 2 & 5 & 1 & 9 \\
\hline Total & & 12 & 2 & 11 & 53 & 17 & 95 \\
\hline
\end{tabular}

Note: Organisation_Size * Social_CRM_Duration crosstabulation.

The following cross-tabulation table shows the dependency between the level of seniority of employees and duration for which they have been using social CRM and it is evident from the table that most executives and managers are using Social CRM for more than two years.

Table 9 Cross tabulation of seniority level and duration of social CRM

\begin{tabular}{cccccccc}
\hline & & \multicolumn{5}{c}{ Social CRM duration } & \\
\cline { 3 - 7 } & & $\begin{array}{c}12 \text { to 18 } \\
\text { months }\end{array}$ & $\begin{array}{c}\text { 18 to 24 } \\
\text { months }\end{array}$ & $\begin{array}{c}\text { 6 to 12 } \\
\text { months }\end{array}$ & $\begin{array}{c}\text { Over 24 } \\
\text { months }\end{array}$ & $\begin{array}{c}\text { Upto 6 } \\
\text { months }\end{array}$ & Total \\
\hline Seniority_Level & Director & 1 & 0 & 3 & 0 & 2 & 6 \\
& Executive & 1 & 0 & 3 & 16 & 3 & 23 \\
& Head of & 0 & 1 & 0 & 1 & 0 & 2 \\
& office & & & & & & \\
& Junior & 0 & 0 & 0 & 8 & 1 & 9 \\
& Manager & 6 & 0 & 2 & 16 & 9 & 33 \\
& Other & 1 & 0 & 0 & 5 & 0 & 6 \\
Total & Senior & 3 & 1 & 3 & 7 & 2 & 16 \\
\hline & 12 & 2 & 11 & 53 & 17 & 95 & \\
\hline
\end{tabular}

Note: Seniority Level* Social_CRM duration crosstabulation.

Social CRM applications and practices are being used in some of the functions of the organisation. To assess the impact of social CRM on the organisational performance, it is imperative to analyse the organisational functions in which Social CRM practices are being employed. Table 10 and Figure 4 illustrate the same. 
Table 10 Functions in which social CRM is used in organisations

\begin{tabular}{lcc}
\hline Functions (in which social CRM is used) & Frequency & Percentage \\
\hline Sales & 40 & 42.1 \\
Marketing & 57 & 60.0 \\
Customer care & 42 & 44.2 \\
Market research & 33 & 34.7 \\
Collaboration & 27 & 28.4 \\
Others & 7 & 7.4 \\
\hline
\end{tabular}

Figure 4 Functions in which social CRM is used in organisations (see online version for colours)

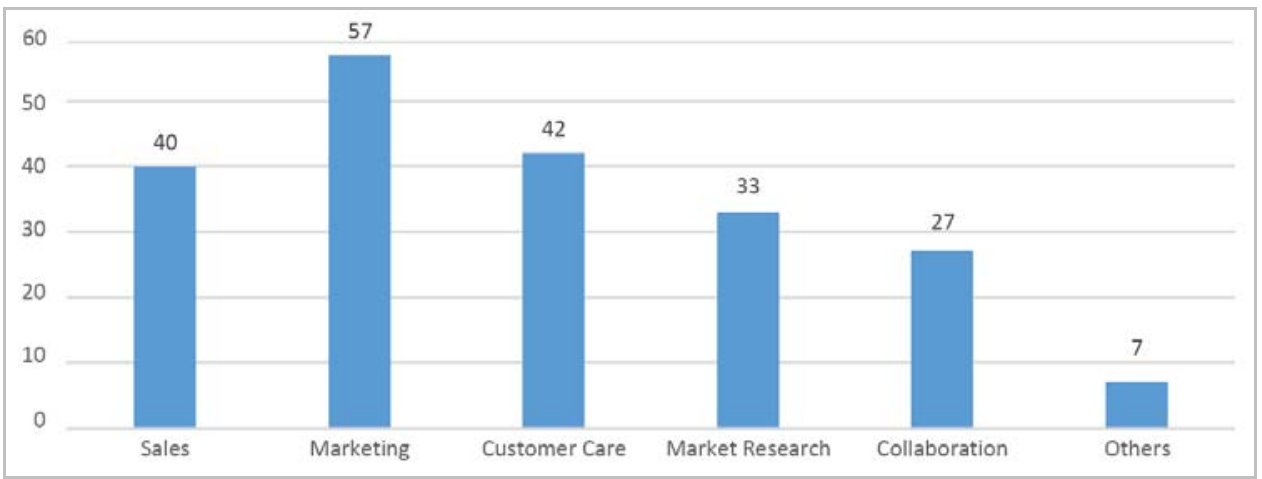

The respondents themselves are performing some of the social CRM functions in the organisations. Table 11 illustrates the tasks that are being performed by the respondents using social CRM. The table gives a better insight into the prominent tasks being performed using social CRM tools and techniques. The table shows that majority (29.47\%) of the respondents are conducting marketing activities using social CRM, followed by customer care practices (17.89\%).

Table 11 Social CRM tasks performed by respondents

\begin{tabular}{lcc}
\hline Social CRM tasks performed by respondents & Frequency & Percentage \\
\hline Collaboration & 13 & 13.68 \\
Customer care & 17 & 17.89 \\
Market research & 12 & 12.63 \\
Marketing & 28 & 29.47 \\
Sales & 15 & 15.78 \\
Other & 10 & 10.52 \\
\hline
\end{tabular}

To determine the dependency between the market type and various functions of SCRM usage, the following cross tabulation has been done. Organisations belonging to Business to business market type are mostly using social CRM functions. Majority of the respondents (38.94\%) of B2B type organisations are using marketing functions of social CRM. 
Figure 5 Social CRM tasks performed by respondents (see online version for colours)

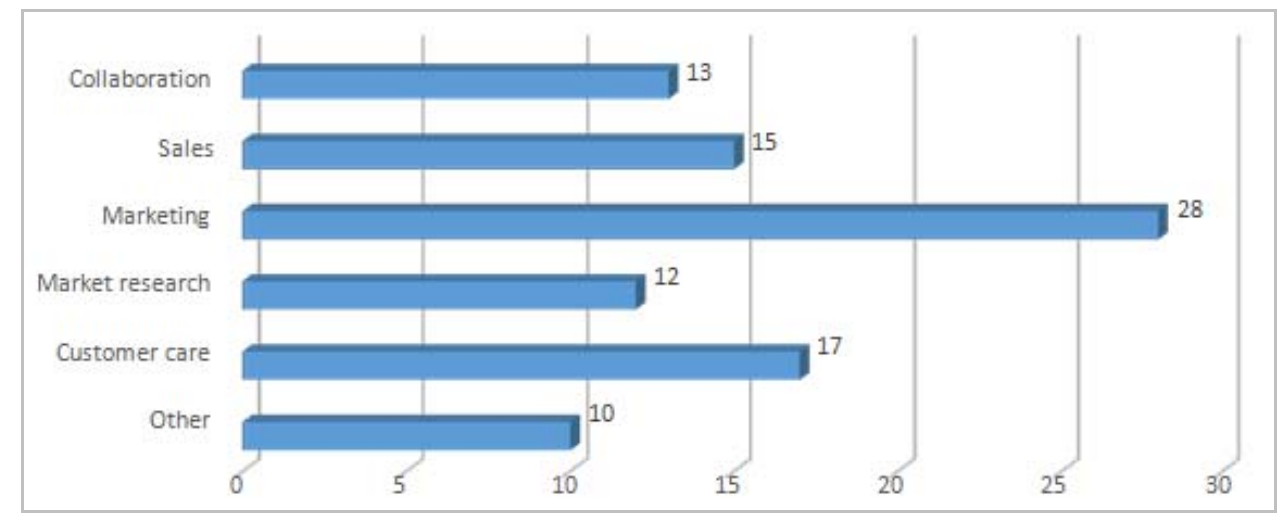

Table 12 Cross tabulation of market type and functions in which social CRM is used

\begin{tabular}{lcccccc}
\hline \multirow{2}{*}{$\begin{array}{l}\text { Market } \\
\text { type }\end{array}$} & Collaboration & $\begin{array}{c}\text { Market } \\
\text { research }\end{array}$ & $\begin{array}{c}\text { Customer } \\
\text { care }\end{array}$ & Marketing & Sales & Other \\
\cline { 2 - 7 } B2B & 20 & 19 & 27 & 37 & 25 & 4 \\
B2C & 7 & 13 & 15 & 20 & 15 & 3 \\
\hline
\end{tabular}

To assess the popularity and usefulness of social CRM functions in an organisation, it is necessary to have an insight into the number of social CRM functions actually being practiced in the organisation. Table 13 exhibits the same.

Table 13 Number of SCRM functions used in organisations

\begin{tabular}{lc}
\hline No. of social CRM functions used in organisations & Frequency \\
\hline 1 function & 42 \\
2 functions & 21 \\
3 functions & 13 \\
4 functions & 13 \\
5 functions & 6 \\
\hline
\end{tabular}

Table 14 Cross tabulation of number of social CRM functions and duration of social CRM

\begin{tabular}{lccccc}
\hline $\begin{array}{l}\text { Number of } \\
\text { social CRM }\end{array}$ & \multicolumn{5}{c}{ Duration of social CRM } \\
\cline { 2 - 6 } functions & $\begin{array}{c}\text { Up to 6 } \\
\text { months }\end{array}$ & $\begin{array}{c}\text { 6 to 12 } \\
\text { months }\end{array}$ & $\begin{array}{c}\text { 12 to 18 } \\
\text { months }\end{array}$ & $\begin{array}{c}\text { 18 to 24 } \\
\text { months }\end{array}$ & $\begin{array}{c}\text { Above 24 } \\
\text { months }\end{array}$ \\
\hline 1 function & 13 & 3 & 2 & 1 & 19 \\
2 functions & 1 & 5 & 4 & 1 & 10 \\
3 functions & 2 & 2 & 1 & 0 & 6 \\
4 functions & 1 & 1 & 1 & 0 & 11 \\
5 functions & 0 & 0 & 1 & 0 & 5 \\
\hline
\end{tabular}


Figure 6 Number of social CRM functions used in organisations (see online version for colours)

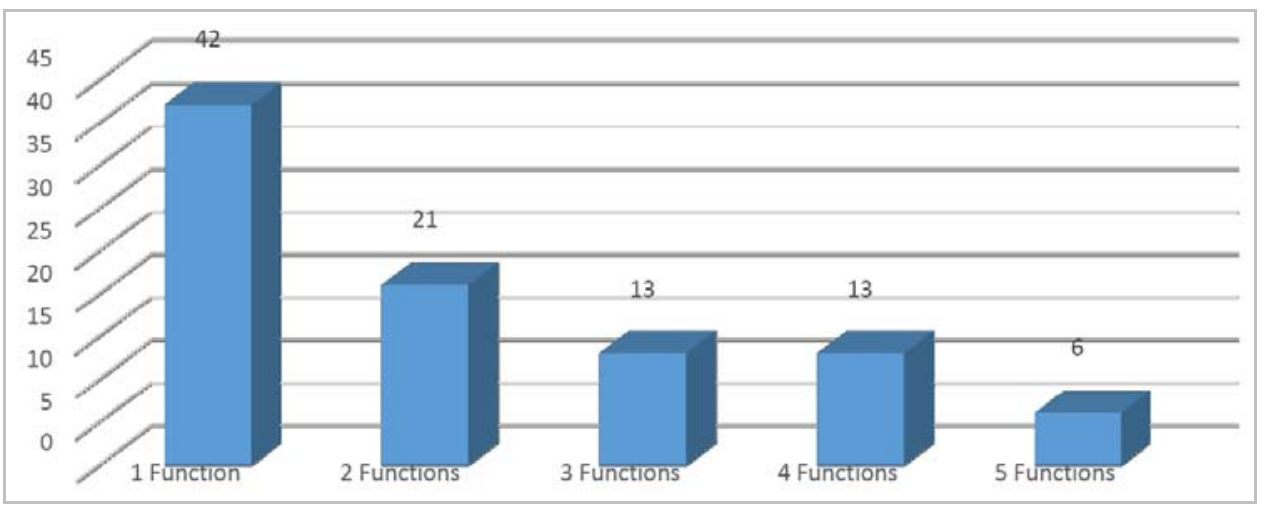

The following cross tabulation shows the dependency between a number of functions for social CRM usage and the duration for which they are used. Majority of the respondents are of the view that they are using one function of social CRM for above 2 years.

\subsubsection{Hypothesis 1}

Null Hypothesis: There is no relationship between use of social CRM and the operative factors.

Alternate Hypothesis: There is a positive relationship between use of Social CRM and the operative factors.

In order to analyse the effect of social CRM on the various operative factors taken in the study, statistical analysis has been performed. There exists a positive relationship between the usage of social CRM in the organisation and the various operative factors taken into account.

The central tendency analysis of customer dimension is illustrated in Table 15.

Table 15 Analysis of central tendency of focus on customer and social CRM

\begin{tabular}{lc}
\hline Central tendency & Values \\
\hline Mean & 4.36315789 \\
Median & 4.35789474 \\
Mode & 4.36842105 \\
Std. deviation & 0.285229 \\
\hline
\end{tabular}

Table 16 Statistical analysis for social CRM and focus on customer

\begin{tabular}{lcc}
\hline Customer focus & Frequency & Percentage \\
\hline Strongly agree & 48 & 50.52 \\
Agree & 38 & 40 \\
Neutral & 9 & 9.47 \\
Disagree & 0 & 0 \\
Strongly disagree & 0 & 0 \\
\hline
\end{tabular}


Mean, median and mode values of customer dimension has come out to be 4 which supports the positive effect of social CRM usage on the customer dimension of the organisation.

About $90 \%$ of respondents have agreed that there exists a significant impact of Social CRM usage on customers' dimension of the organisation. Table 16 illustrates the same.

The central tendency analysis of competitor dimension is illustrated in Table 17.

Table 17 Analysis of central tendency of focus on competitor and social CRM

\begin{tabular}{lc}
\hline Central tendency & Values \\
\hline Mean & 4.105263158 \\
Median & 4.115789474 \\
Mode & 4.126315789 \\
Std. deviation & 0.3019 \\
\hline
\end{tabular}

Mean, median and mode values of competitor dimension has come out to be 4 which supports the positive effect of social CRM usage on the competitor dimension of the organisation.

About $82 \%$ of respondents have agreed that there exists a significant impact of social CRM usage on competitors' dimension in the organisation. Table 18 illustrates the same.

Table 18 Statistical analysis for social CRM and focus on competitor

\begin{tabular}{lcc}
\hline Competitor focus & Frequency & Percentage \\
\hline Strongly agree & 37 & 38.94 \\
Agree & 41 & 43.15 \\
Neutral & 16 & 16.84 \\
Disagree & 0 & 0 \\
Strongly disagree & 1 & 1.05 \\
\hline
\end{tabular}

The central tendency analysis of marketing intelligence dimension is illustrated in Table 9.

Table 19 Analysis of central tendency of marketing intelligence and social CRM

\begin{tabular}{lc}
\hline Central tendency & Values \\
\hline Mean & 4.147368 \\
Median & 4.247368 \\
Mode & 4.242105 \\
Std. deviation & 0.455221 \\
\hline
\end{tabular}

Mean, median and mode values of marketing intelligence dimension has come out to be 4 which supports the positive effect of social CRM usage on the marketing intelligence dimension of the organisation.

About $87 \%$ of respondents have agreed that there exists a significant impact of social CRM usage on the marketing intelligence dimension of the organisation. Table 20 illustrates the same: 
Table 20 Statistical analysis for social CRM and marketing intelligence

\begin{tabular}{lcc}
\hline Marketing intelligence & Frequency & Percentage \\
\hline Strongly agree & 36 & 37.89 \\
Agree & 47 & 49.47 \\
Neutral & 11 & 11.57 \\
Disagree & 1 & 1.05 \\
Strongly disagree & 0 & 0 \\
\hline
\end{tabular}

The central tendency analysis of cross-function collaboration is illustrated Table21.

Table 21 Analysis of central tendency of cross functional collaboration and social CRM

\begin{tabular}{lc}
\hline Central tendency & Values \\
\hline Mean & 4.013158 \\
Median & 4.063158 \\
Mode & 4.031579 \\
Std. deviation & 0.393158 \\
\hline
\end{tabular}

Mean, median and mode values of cross-functional dimension has come out to be 4 which supports the positive effect of social CRM usage on the marketing intelligence dimension of the organisation.

About $76 \%$ of respondents have agreed that there exists a significant impact of social CRM usage on the cross-functional collaboration of various departments in the organisation. Table 22 illustrates the same.

Table 22 Statistical analysis for social CRM and cross functional collaboration

\begin{tabular}{lcc}
\hline Cross functional collaboration & Frequency & Percentage \\
\hline Strongly agree & 37 & 38.94 \\
Agree & 35 & 36.84 \\
Neutral & 21 & 22.1 \\
Disagree & 2 & 2.1 \\
Strongly disagree & 0 & 0 \\
\hline
\end{tabular}

For developing better understanding between operative factors and the size of organisation, the following cross tabulation analysis have been performed. Cross-tabulations have been performed among following variables:

- organisation size and customer dimension

- organisation size and competitor dimension

- organisation size and marketing intelligence

- organisation size and cross-functional collaboration. 
Table 23 Cross tabulation of organisation size and customer dimension

\begin{tabular}{lcccccc}
\hline & \multicolumn{5}{c}{ Customer } & Total \\
\cline { 3 - 6 } & & Disagree & Neutral & Agree & Strongly agree & \\
\hline $\begin{array}{l}\text { Organisation } \\
\text { size }\end{array}$ & $\begin{array}{c}\text { Up to 200 } \\
\text { employees } \\
201 \text { to 500 } \\
\text { employees }\end{array}$ & 0 & 2 & 6 & 1 & 9 \\
& $\begin{array}{c}501 \text { to 1,000 } \\
\text { employees } \\
1,001 \text { to } \\
5,000\end{array}$ & 0 & 0 & 4 & 2 & 6 \\
employees & 0 & 1 & 9 & 1 & 5 \\
Above 5,000 \\
employees
\end{tabular}

Note: Organisation size * Customer cross tabulation count.

Table 24 Cross tabulation of organisation size and competitor dimension

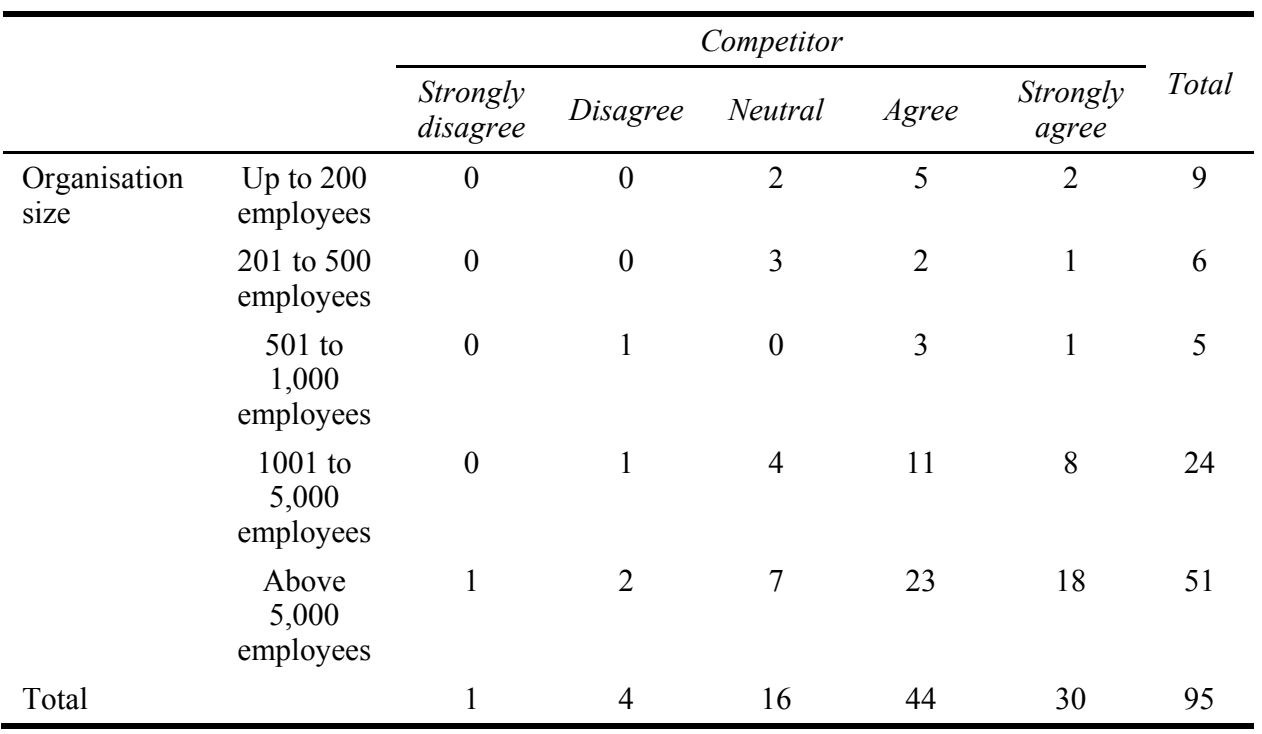

Note: Organisation size * Competitor cross tabulation count.

On an average, each operative factor gets affected by $83.75 \%$ on account of social CRM usage. Therefore, after quantitatively analysing the data, the null hypothesis is rejected and alternate hypothesis there is a positive relationship between use of social CRM and the operative factors is accepted. 
Table 25 Cross tabulation of organisation size and marketing intelligence

\begin{tabular}{|c|c|c|c|c|c|c|}
\hline & & \multicolumn{4}{|c|}{ Marketing_Intelligence } & \multirow{2}{*}{ Total } \\
\hline & & Disagree & Neutral & Agree & Strongly agree & \\
\hline \multirow[t]{5}{*}{$\begin{array}{l}\text { Organisation } \\
\text { size }\end{array}$} & $\begin{array}{l}\text { Up to } 200 \\
\text { employees }\end{array}$ & 0 & 2 & 5 & 2 & 9 \\
\hline & $\begin{array}{l}201 \text { to } 500 \\
\text { employees }\end{array}$ & 0 & 3 & 1 & 2 & 6 \\
\hline & $\begin{array}{c}501 \text { to } \\
1,000 \\
\text { employees }\end{array}$ & 1 & 0 & 3 & 1 & 5 \\
\hline & $\begin{array}{c}1,001 \text { to } \\
5,000 \\
\text { employees }\end{array}$ & 0 & 1 & 14 & 9 & 24 \\
\hline & $\begin{array}{c}\text { Above } \\
5,000 \\
\text { employees }\end{array}$ & 0 & 10 & 20 & 21 & 51 \\
\hline Total & & 1 & 16 & 43 & 35 & 95 \\
\hline
\end{tabular}

Note: Organisation size * Marketing intelligence cross tabulation count.

Table 26 Cross tabulation of organisation size and cross functional collaboration

\begin{tabular}{|c|c|c|c|c|c|c|c|}
\hline & & \multicolumn{5}{|c|}{ Cross functional } & \multirow[b]{2}{*}{ Total } \\
\hline & & $\begin{array}{l}\text { Strongly } \\
\text { disagree }\end{array}$ & Disagree & Neutral & Agree & $\begin{array}{c}\text { Strongly } \\
\text { agree }\end{array}$ & \\
\hline \multirow[t]{5}{*}{$\begin{array}{l}\text { Organisation } \\
\text { size }\end{array}$} & $\begin{array}{l}\text { Up to } 200 \\
\text { employees }\end{array}$ & 0 & 0 & 3 & 5 & 1 & 9 \\
\hline & $\begin{array}{l}201 \text { to } 500 \\
\text { employees }\end{array}$ & 0 & 0 & 4 & 1 & 1 & 6 \\
\hline & $\begin{array}{c}501 \text { to } \\
1,000 \\
\text { employees }\end{array}$ & 1 & 0 & 3 & 0 & 1 & 5 \\
\hline & $\begin{array}{c}1,001 \text { to } \\
5,000 \\
\text { employees }\end{array}$ & 0 & 0 & 5 & 12 & 7 & 24 \\
\hline & $\begin{array}{c}\text { Above } \\
5,000 \\
\text { employees }\end{array}$ & 0 & 3 & 11 & 19 & 18 & 51 \\
\hline Total & & 1 & 3 & 26 & 37 & 28 & 95 \\
\hline
\end{tabular}

Note: Organisation size * Cross functional cross tabulation count.

\subsubsection{Hypothesis 2}

Null Hypothesis: There is no relationship between social CRM duration and operative factors.

Alternate Hypothesis: There is a positive relationship between social CRM duration and operative factors. 
Table 27 Correlation between social CRM duration and operative factors

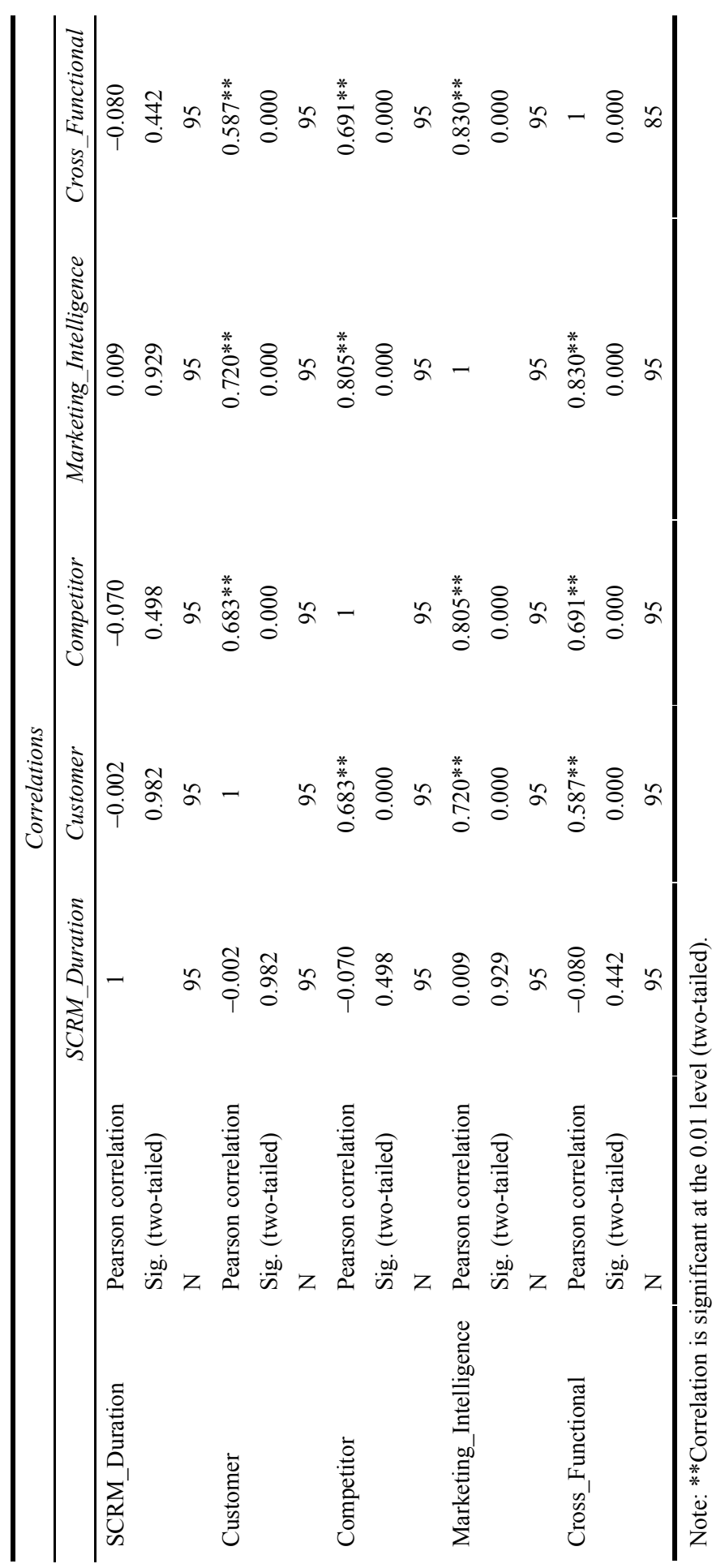


Pearson correlation method is used to examine the relationship between duration of social CRM use and the various operative factors. The linear dependency between these the above two variables is measured to determine the strength of dependency between them.

The following conclusions can be drawn from Table 27.

1 the Pearson correlation coefficient between the social CRM duration and customer focus is -0.002 (relationship is negligible)

2 the Pearson correlation coefficient between the social CRM duration and competitor focus is -0.070 (relationship is negligible)

3 the Pearson correlation coefficient between the social CRM duration and marketing intelligence is 0.009 (relationship is negligible)

4 the Pearson correlation coefficient between the social CRM duration and crossfunctional collaboration is -0.080 (relationship is negligible).

For the relationship to be significant, the Pearson correlation value needs to be close to +1 (positive correlation) and -1 (negative correlation). As it can be inferred from Table 27 that the correlation coefficient values between social CRM duration and various operative factors are weak or negligible from both positive as well as negative side. Therefore, there exists no relationship between the two considered variables.

Thus, the null hypothesis there is no relationship between social CRM duration and operative factors is accepted (see Appendix A).

\subsubsection{Hypothesis 3}

Null Hypothesis: There is no relationship between the operative factors and the functions count for which social CRM is used.

Alternate Hypothesis: There is a significant relationship between the operative factors and the functions count for which social CRM is used.

Pearson correlation method is used to examine the relationship between a number of functions for which social CRM is used and the various operative factors. The linear dependency between these the above two variables is measured to determine the strength of dependency between them.

The following conclusions can be drawn from Table 28 .

1 the Pearson correlation coefficient between the functions count for which social CRM is used and customer focus is 0.202 (relationship is weakly positive)

2 the Pearson correlation coefficient between the functions count for which social CRM is used and competitor focus is 0.140 (relationship is weakly positive)

3 the Pearson correlation coefficient between functions count for which social CRM is used and marketing intelligence is 0.118 (relationship is weakly positive)

4 the Pearson correlation coefficient between the functions count for which social CRM is used and cross-functional collaboration is -0.040 (relationship is negligible). 
Table 28 Correlation between number of functions for which social CRM is used and operative factors

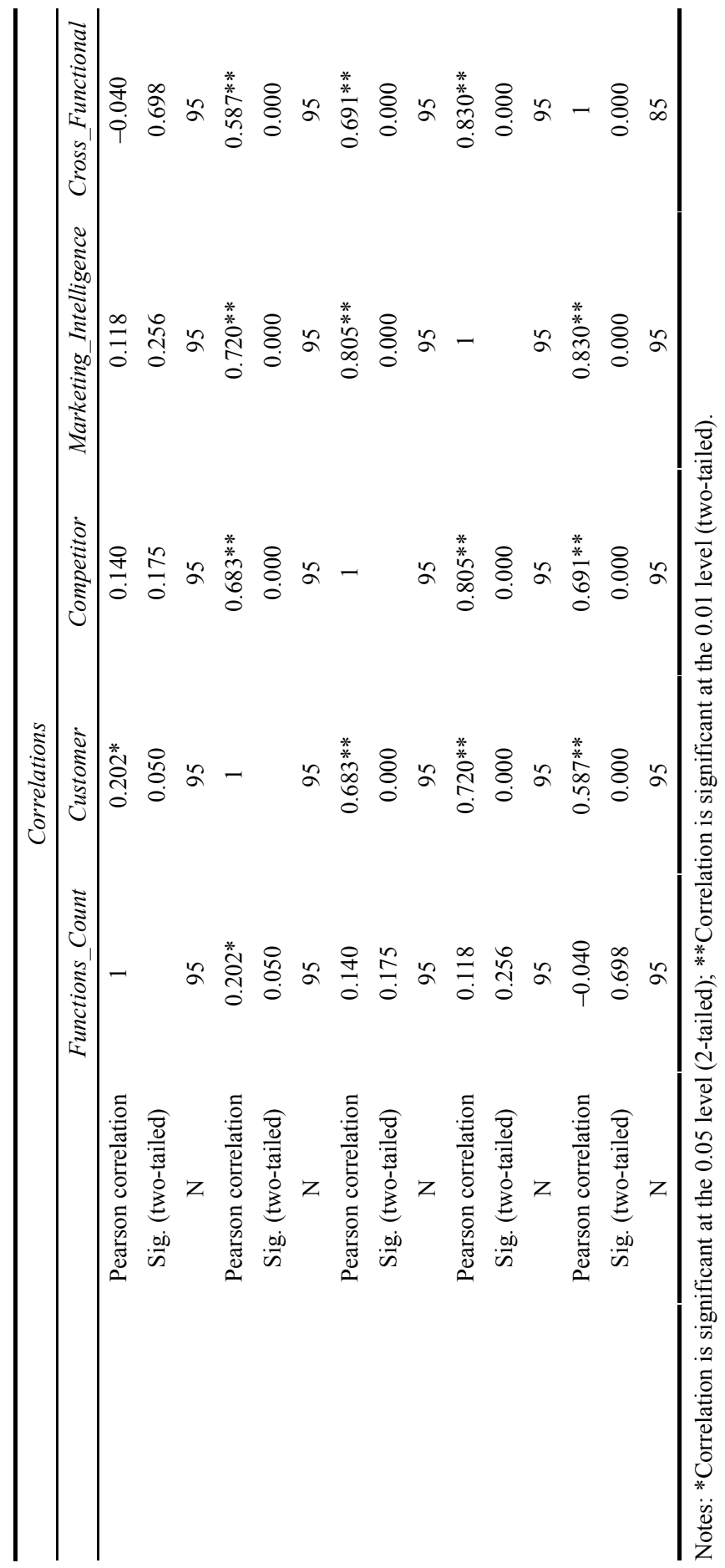


For the relationship to be significant, the Pearson correlation value needs to be close to +1 (positive correlation) and -1 (negative correlation). As it can be inferred from the above table that the correlation coefficient values between the numbers of functions for which social CRM are used and various operative factors are weakly positive. Therefore, there exists a weak relationship between the two considered variables.

Since one of the operative factors has a negligible relationship with the functions count for which social CRM is used and the remaining three operative factors have a somewhat positive relationship with functions count.

Therefore, we reject the null hypothesis and the alternate hypothesis that there is a significant relationship between the operative factors and the functions count for which social CRM is used is acceptable (see Appendix B).

\subsubsection{Hypothesis 4}

Null Hypothesis: There is no impact of operative factors on social CRM performance measures.

Alternate Hypothesis: There is a significant impact of operative factors on social CRM performance measures.

Structural equation modelling (SEM) is used to analyse the data empirically and is being widely used and applied in different disciplines such as political science, psychology, sociology, strategy, marketing and management research. The model consists of two parts:

a measurement model, showing the relationship between observed variables and latent variables

b structural model, exhibiting the relationship between the latent variables.

Figure 7 Path diagram using structural equation modelling (see online version for colours)

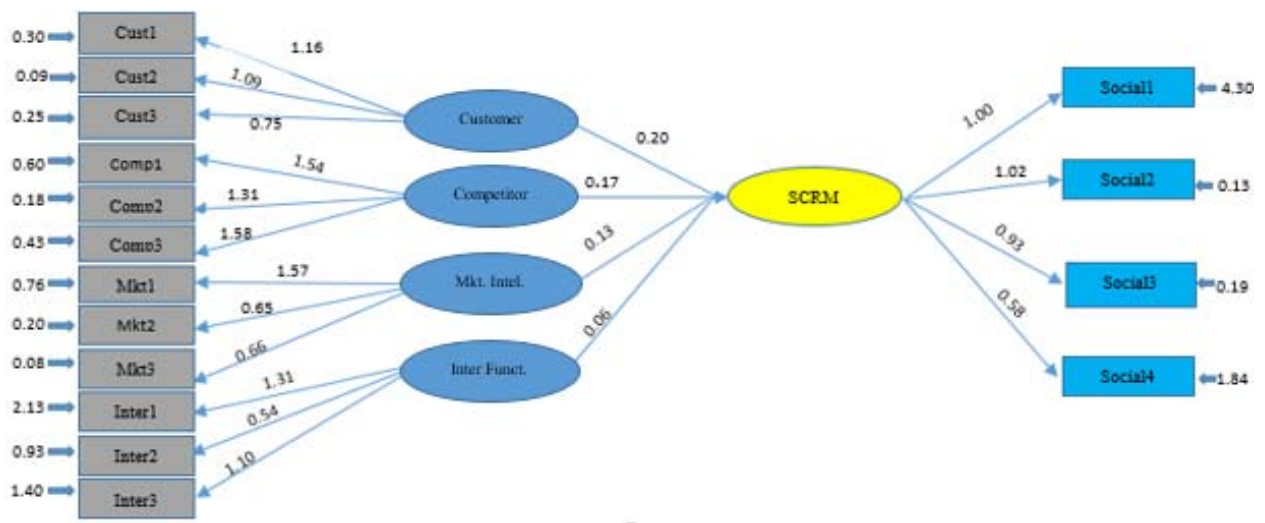

SEM exhibits the fit statistics and compares the proposed model to the data collected empirically. It can be used to estimate the impact of these operative factors on Social CRM performance. The proposed model consists of five variables which are latent in nature and can be measured using their respective observed variables. The software used 
for SEM IS LISREL 9.30. The five latent variables are customer focus, competitor focus, marketing intelligence, cross-functional collaboration or inter-functional collaboration and social CRM performance. The following figure illustrates the pattern and the relationship of these latent variables. The observed variables are entered into the software as Cust1, Cust2, Cust3 for the latent variable 'customer', measuring the operating factor 'customer focus'. Similarly, Comp1, Comp2, Comp3 represents the observed variables for the 'competitor' latent variable used for measuring the 'competitor focus' operating factor. Also, Mkt1, Mkt2, Mkt3 are the observed variables for 'marketing intelligence' latent variable. Inter1, Inter2, Inter3 denoted the observed variables for 'inter functional or cross-functional collaboration' latent variable. Similarly, Social1, Social2, Social3, Social4 are the observed variables for 'social CRM or SCRM' latent variable.

There are certain statistics available while using SEM which indicates the fitment of the model to the observed data. There are three goodness-of-fit-statistics available which can be used to estimate the fitment of the proposed model:

a adjusted goodness of fit index (AGFI), where the value should be greater than 0.80 for the model to be called fit

b root mean residual (RMR), where the figure should be less than 0.10 is desired

c comparative fit index (CFI), where the score should be greater than 0.90 is preferred (Bentler, 1990).

Figure 8 Correlation analysis

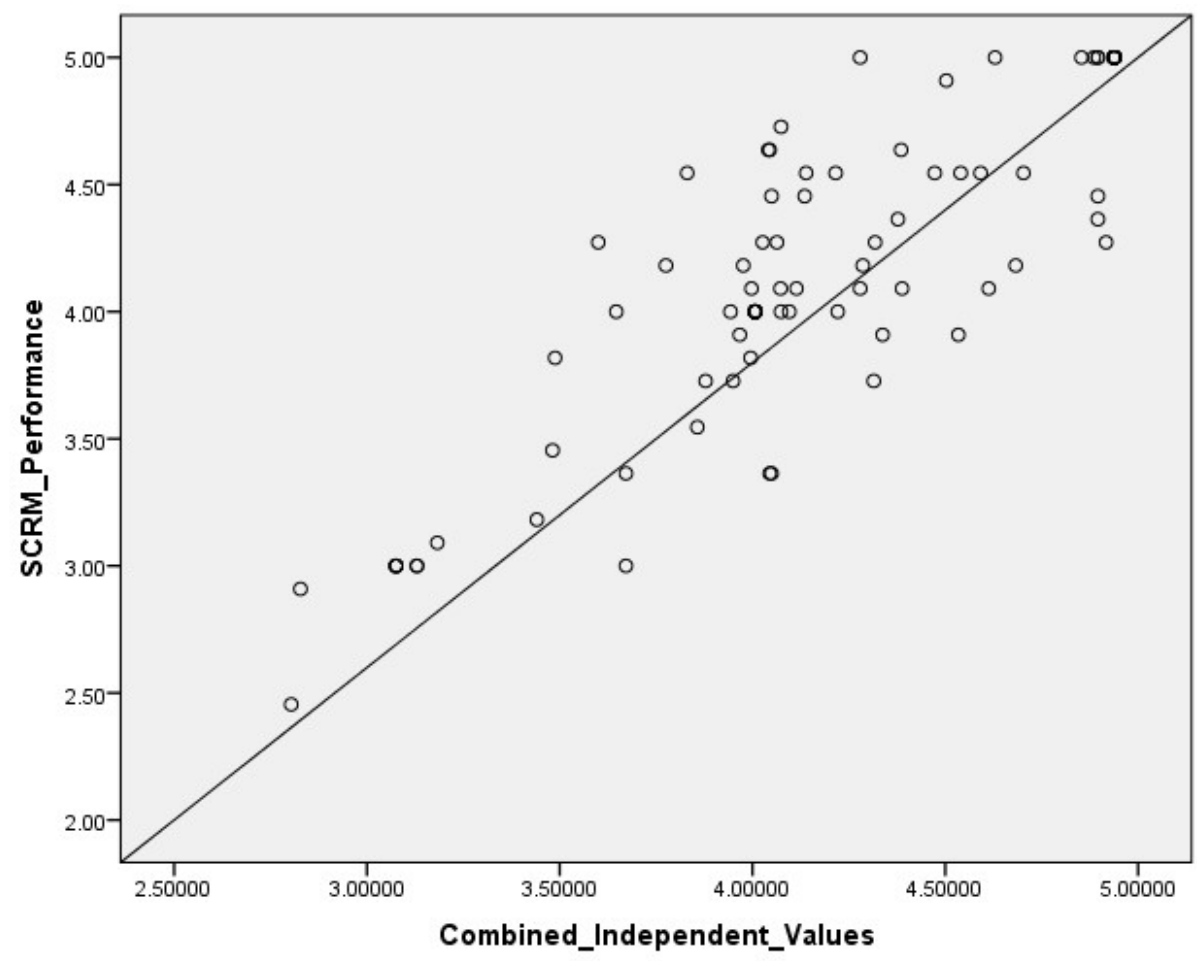


Table 29 Correlation analysis

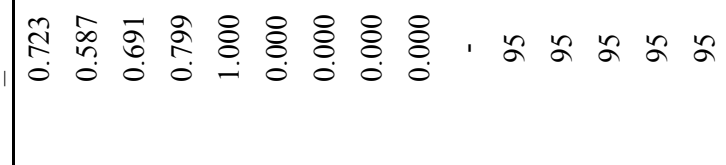

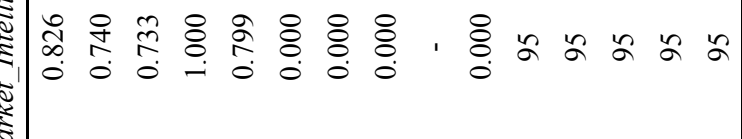

$$
\begin{aligned}
& \text { है }
\end{aligned}
$$

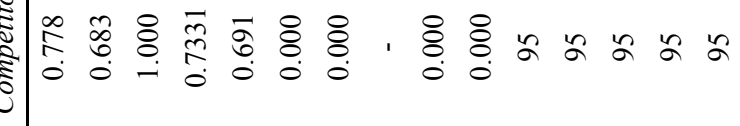

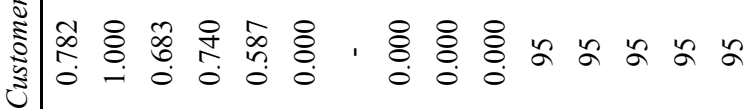

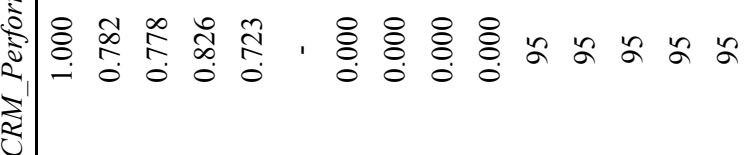

$$
\begin{aligned}
& \text { 过 }
\end{aligned}
$$

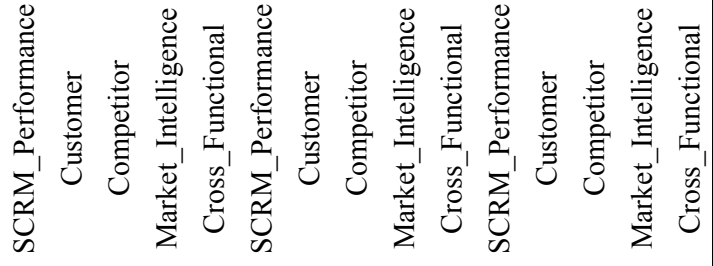

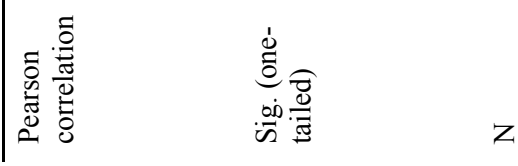$$
\text { \% }
$$ 
In this study, the value of AGFI associated with this model is 0.92 and the RMR $=0.030$ (see Appendix E). The value of CFI is 1.00. All the above statistical values indicate the appropriate fitment of the model with the observed data.

Also, the root mean square error of approximation (RMSEA) test suggests a score of 0.05 or less than 0.05 to be an appropriate fit. The RMSEA value is 0.026 , which is less than 0.05 , indicates a good fit of the proposed model.

Correlation measures the degree of association between various independent and dependent variables. Karl Pearson's coefficient of correlation $(\mathrm{R})$ is used to measure quantitatively the degree of relationship between the variables. The value of $r$ should be greater than or equal to 0.50 for moderate positive correlation. The value of Pearson correlation between customer focus factor and SCRM measurement for performance is 0.782 , between competitor and SCRM performance is 0.778 , between marketing intelligence and performance, is 0.826 and between cross-functional collaboration and performance is 0.723 .

The coefficient of determination ( $\mathrm{R}$ square) measures the fitness of regression models. The proportion of variation in the dependent variable due to the considered independent variable is measured using $\mathrm{R}$ square value. Its value is found to be 0.784 . Table 30 shows that 78.4 percentage of variance in social CRM performance measurement can be accounted for with the help of operative factors considered as independent variables.

Table 30 Estimated coefficient of determination

\begin{tabular}{ccccc}
\hline \multirow{2}{*}{ Hypothesis 1} & $R$ & R-square & $\begin{array}{c}\text { Adjusted } R \text { - } \\
\text { square }\end{array}$ & $\begin{array}{c}\text { Std. error of the } \\
\text { estimate }\end{array}$ \\
\cline { 2 - 5 } & 0.886 & 0.784 & 0.775 & 0.31128 \\
\hline
\end{tabular}

The regression model examining the impact of operative factors on social CRM performance is $\mathrm{y}=0.281+.325 \mathrm{x} 1+0.212 \times 2+0.309 \times 3+0.085 \times 4$, y denotes measurement of Social CRM performance, $\mathrm{x} 1$ denotes customer focus, $\mathrm{x} 2$ denotes competitor focus, $\mathrm{x} 3$ denotes marketing intelligence and $\mathrm{x} 4$ denote cross-functional collaboration.

Table 31 Regression model

\begin{tabular}{lcccc}
\hline \multirow{2}{*}{ Hypothesis 1} & \multicolumn{2}{c}{ Unstandardised coefficients } & & \multicolumn{2}{c}{ Standardised coefficients } \\
\cline { 2 - 3 } & $B$ & Std. error & \\
\hline (Constant) & 0.281 & 0.237 & \\
Customer & 0.325 & 0.083 & 0.300 \\
Competitor & 0.212 & 0.065 & 0.258 \\
Marketing intelligence & 0.309 & 0.094 & 0.332 \\
Cross functional & 0.085 & 0.069 & 0.104 \\
\hline
\end{tabular}

The regression and correlation analysis is examined using the p-value.

The significance value is less than alpha for the three operative factors i.e. customer, competitor, market intelligence at $95 \%$ confidence level. Thus, we failed to accept the null hypothesis and hence alternate hypothesis H1: there is a significant impact of operative factors on social CRM performance measures, is accepted (see Appendix C). 
Table 32 Regression and correlation analysis

\begin{tabular}{lccc}
\hline Hypothesis & Significance $(p$ value $)$ & Alpha & Decision \\
\hline Customer & 0.000 & 0.05 & Reject the null hypothesis \\
Competitor & 0.002 & 0.05 & \\
Marketing intelligence & 0.001 & 0.05 & \\
Cross functional & 0.222 & 0.05 & \\
\hline
\end{tabular}

\subsubsection{Hypothesis 5}

Null Hypothesis: There is no variation regarding social CRM duration between B2B and B2C market types.

Alternate Hypothesis: There is significant variation regarding social CRM duration between B2B and B2C market types.

Table 33 Social CRM duration across market type

\begin{tabular}{llcccccc}
\hline & & \multicolumn{7}{c}{ Social CRM duration } & \multirow{2}{*}{ Total } \\
\cline { 3 - 7 } & & $\begin{array}{c}\text { Up to 6 } \\
\text { months }\end{array}$ & $\begin{array}{c}\text { 6 to 12 } \\
\text { months }\end{array}$ & $\begin{array}{c}\text { 12 to 18 } \\
\text { months }\end{array}$ & $\begin{array}{c}\text { 18 to 24 } \\
\text { Months }\end{array}$ & $\begin{array}{c}\text { Over 24 } \\
\text { months }\end{array}$ & \\
\hline Market & B2B & 11 & 7 & 8 & 2 & 33 & 61 \\
type & B2C & 6 & 4 & 4 & 0 & 20 & 34 \\
& Total & 17 & 11 & 12 & 2 & 53 & 95 \\
\hline
\end{tabular}

Table 34 Chi square analysis

\begin{tabular}{lccc}
\hline Hypothesis & Significance $(p$ value $)$ & Alpha & Decision \\
\hline H5 & 0.872 & 0.05 & Accept the null hypothesis \\
\hline
\end{tabular}

Table 35 Hypothesis summary

\begin{tabular}{|c|c|c|c|}
\hline \multicolumn{2}{|c|}{ Hypothesis } & \multirow{2}{*}{$\begin{array}{c}\text { Conditionality } \\
83.75 \text { (percent by which each } \\
\text { operative factor gets effected) }\end{array}$} & \multirow{2}{*}{$\frac{\text { Result }}{\text { Supported }}$} \\
\hline $\mathrm{H} 1$ & $\begin{array}{l}\text { There is a positive relationship } \\
\text { between use of social CRM and the } \\
\text { operative factors. }\end{array}$ & & \\
\hline $\mathrm{H} 2$ & $\begin{array}{l}\text { There is a positive relationship } \\
\text { between social CRM duration and } \\
\text { operative factors. }\end{array}$ & $\begin{array}{l}\text { Negligible correlation } \\
\text { coefficient }\end{array}$ & Not supported \\
\hline H3 & $\begin{array}{l}\text { There is a significant relationship } \\
\text { between the operative factors and } \\
\text { the number of functions for which } \\
\text { social CRM is used }\end{array}$ & $\begin{array}{l}\text { Moderate correlation } \\
\text { coefficient }\end{array}$ & Supported \\
\hline $\mathrm{H} 4$ & $\begin{array}{l}\text { There is significant impact of } \\
\text { operative factors on social CRM } \\
\text { performance measures. }\end{array}$ & 0.05 (significance value) & Supported \\
\hline H5 & $\begin{array}{l}\text { There is significant variation } \\
\text { regarding social CRM duration } \\
\text { between B2B and B2C market types. }\end{array}$ & 0.872 (significance value) & Not supported \\
\hline
\end{tabular}


Chi-square test of independence is examined to observe the relationship between social CRM duration across two different market types.

At $95 \%$ of confidence level, the significance value is found to be greater than alpha (0.05). This helps in establishing the fact that the null hypothesis: There is no variation regarding social CRM duration between $\mathrm{B} 2 \mathrm{~B}$ and $\mathrm{B} 2 \mathrm{C}$ market types, is accepted (see Appendix D).

\section{Discussion and conclusions}

\subsection{Summary of results}

On the basis of data analysis of 95 respondents from different industries, it is concluded that there is a positive relationship between use of social CRM and the operative factors (customer focus, competitor focus, marketing intelligence and cross-functional collaboration). There is a considerable contribution from Information Technology industry constituting around $72 \%$ whereas rest is from other industries including banking, hospitality, manufacturing, etc. The majority of respondents are from industries which are having more than 5,000 employee size. Around $64.21 \%$ of respondents are from industries operating in B2B market type while rest $35.71 \%$ are from industries operating in $\mathrm{B} 2 \mathrm{C}$ market type. The social media platform which companies are using majorly consist of LinkedIn (52.63\%) followed by Facebook (51.57\%) followed by blogs/forums $(46.31 \%)$ and then followed by Twitter (41.05\%) and YouTube channels (28.42\%). Also, the seniority level of the respondents who have replied to the survey is as follows: manager (34.735), executive (24.215), senior (16.84\%), junior $(9.47 \%)$ followed by director and head of the office. Majority of the respondents (55.78\%) are using the social CRM for more than 24 months followed by $17.89 \%$ of the respondents who are using the social CRM for up to six months in their organisation. Around $60 \%$ of the respondents are using social CRM for marketing function followed by customer care (44.2\%), sales (42.1\%), markets research and collaboration activities. On the basis of various central tendency measures and different crosstabs, it is realised that each operative factor gets affected by $83.75 \%$ on account of social CRM usage. This validates the first hypothesis of the study that there is a positive relationship between use of social CRM and the operative factors.

The SEM attempts to model the observed data and bring about a significant relationship between the operative factors and the performance of the organisation after the implementation of social CRM practices. The results of goodness-of-fit statistics reveal some very important inferences and conclusions. The values of $\mathrm{RMR}=0.03$, $\mathrm{AGFI}=0.92, \mathrm{CFI}=1.00$ and RMSEA $=0.026$ indicates that the model is in accordance to the desired statistics. Therefore, it can be safely inferred that there is a significant impact of operative factors or the four latent variables (customer focus, competitor focus, marketing intelligence and cross-functional collaboration) on the fifth latent variable of the model or the social CRM organisational performance. The resulting model of SEM validates the fact that focusing explicitly on customers, their needs, demands and temperament and also on the competitors' activities will provide the organisation with a competitive advantage. Marketing intelligence activities facilitated through social CRM practices and cross-functional collaboration in the organisation through social 
CRM techniques are yet another set of significant factors resulting in the enhanced organisational performance. All the above findings are substantiated with the help of the model developed through SEM.

Correlation analysis between social CRM duration and operative factors verifies the second hypothesis of the study, i.e., there is no relationship between social CRM duration and operative factors. Also on the basis of correlation analysis between a number of functions for which social CRM is used and operative factors, the third hypothesis of the study is established, i.e., there is a significant relationship between the operative factors and the functions count for which social CRM is used. Regression and correlation analysis is used to find the impact of operative factors on social CRM performance measures and the regression equation is found to be $\mathrm{y}=0.281+.325 \times 1+0.212 \times 2+$ $0.309 \times 3+0.085 \times 4$, y denotes measurement of social CRM performance, $\mathrm{x} 1$ denotes customer focus, $\mathrm{x} 2$ denotes competitor focus, $\mathrm{x} 3$ denotes marketing intelligence and $\mathrm{x} 4$ denotes cross-functional collaboration, validates the fourth hypothesis of the study that there is a significant impact of operative factors on social CRM performance measures. Also, the chi-square analysis is used to find out the significant variation regarding social CRM duration between B2B and B2C market types and as from the above analysis, it is found that that there is no variation regarding social CRM duration between B2B and B2C market types.

\subsection{Limitations}

One of the limitations of the study is that the sample chosen for the study would not be representing the whole population and the results cannot be generalised on the basis of the above findings. Another limiting factor inhibiting the findings is the biases with which respondents are responding the questions. Researcher's biases also prevail in selecting the respondents and sending the questionnaire.

The research instrument employed in the study is just questionnaire which is not completely sufficient to collect the data. Some other data collection tools need to be employed in conjunction with it.

Sample size could be expanded to a higher magnitude and more exposure to other industries is possible. There is no comparison being made among the type of industries and organisations participating in the research.

\subsection{Conclusions and managerial implications}

Secondary data collection and analysis shed significant light on the importance of social CRM practices and its implementation in the organisation for the improved performance of the organisation. The process of social media deployment within traditional CRM practices is a paradigm shift. It is an exclusive and rapidly emerging business strategy (Trainor et al., 2014). Social CRM helps businesses and organisations in gaining significant insights about customers and building customer loyalty, enriching customer experiences by creating opportunities for organisations in terms of differentiated products and services, along with substantially lowering the service cost of the organisations. The approach adopted by social CRM practices involves consumer-centric methods and practices. It includes increased participation of consumers in organisational processes, which in turn yields mutual benefit for both consumers and the organisations (Choudhury 
and Harrigan, 2014). The organisation has started prospecting customers as a collaborative partner, where they are contributing to the creation and production of content about the products and services of the organisation over social media platforms (Vargo and Lusch, 2016). The sales performance of the organisations is found to be considerably increased by the virtue of social CRM usage. The alignment of the organisation with the current market needs has improved along with improved sales and a better understanding of customer's needs (Rodriguez et al., 2014). The increase in social media operability by consumers has given birth to terminology called 'social consumer'. Social CRM applications impart greater transparency and increased credibility in developing the sustainable relationship with consumers (Cappuccio et al., 2012). All the findings and inferences made on the basis of secondary data reports are being substantiated by the primary data analysis. Applications of successful techniques and strategies of social CRM is the need of the hour to stay ahead and remain competitive in the market (Kubina and Lendel, 2014).

Social media is undoubtedly having the positive impact on the performance growth of the organisation. If properly appreciated and used, it has the potential of leveraging huge growth for the organisation. To assess the social CRM practices and its various activities implemented in the organisation, certain performance measures needs to be identified. These measures work as the benchmarks against which the potential growth of the organisation is evaluated. Customer lifetime value, brand awareness, competitive advantage, financial benefits, new product performance and customer interaction and orientation from social media perspective are the performance parameters of the organisation (Küpper et al., 2014).

Social CRM practices are just enabling the growth of the organisation by compounding the results that could be achieved by traditional CRM alone. Social media is no doubt benefitting organisations in numerous ways. The considered factors of social CRM along four dimensions such as customer, competitor, generating marketing intelligence and extending cross collaboration are having a considerable impact on the overall performance of the organisation. Marketers need to fully utilise these four factors in establishing outstanding relationships and continuous interactions with the customers.

All the above-identified factors are qualified and are having a positive relationship with social CRM. After SCRM implementation, all the operative issues or the factors are showing positive results which exhibit the positive impact of social CRM usage in the organisation.

The identified factors are found to be indifferent towards the time duration for which social CRM is used. Thus, social CRM duration has an insignificant relationship with the operative factors. The four identified operating factors are being moderately benefitted by increasing the number of functions for which social CRM is used. Thus, the number of functions for which social CRM is used in the organisation is having a weakly positive relationship with the operative factors working in the social CRM domain.

The findings of the study would facilitate managers in their decision-making capabilities and can significantly improve the process of implementing the social CRM practices in the organisation. On academic front also, the study makes a significant contribution. It provides academic society with impactful knowledge and important insight into the market-oriented operative factors and their interplay in the social media domain over a wide variety of issues. It also opens up new avenues and research possibilities for academicians. 


\section{References}

Agnihotri, R. et al. (2017) 'Examining the role of sales-based CRM technology and social media use on post-sale service behaviors in India', Journal of Business Research, Vol. 81, pp.144-154.

Ahani, A., Rahim, N.Z.A. and Nilashi, M. (2017) 'Forecasting social CRM adoption in SMEs: a combined SEM-neural network method', Computers in Human Behavior, Vol. 75, pp.560-578.

Ananda, A.S. et al. (2016) 'N-REL: a comprehensive framework of social media marketing strategic actions for marketing organizations', Journal of Innovation \& Knowledge, September-December, Vol. 1, No. 3, pp.170-180.

Baird, C.H. and Parasnis, G. (2011) 'From social media to social customer relationship management', Strategy \& Leadership, Vol. 39, No. 5, pp.30-37.

Bentler, P.M. (1990) 'Comparative fit indexes in structural models', Psychological Bulletin, March, Vol. 107, No. 2, pp.238-246.

Cappuccio, S., Kulkarni, S., Sohail, M., Haider, M. and Wang, X. (2012) 'Social CRM for SMEs: current tools and strategy', Contemporary Research on E-business Technology and Strategy, Communications in Computer and Information Science, Vol. 332, pp.422-435.

Charoensukmongkol, P. and Sasatanun, P. (2017) 'Social media use for CRM and business performance satisfaction: the moderating roles of social skills and social media sales intensity', Asia Pacific Management Review, Vol. 22, No. 1, pp.25-34.

Charron, C., Favier, J. and Li, C. (2006) Forrester Big Idea: Social Computing - How Networks Erode Institutional Power and What to do About it, 13 February, Forrester Research, Inc. [online] https://www.cisco.com/web/offer/socialcomputing/SocialComputingBigIdea.pdf.

Choudhury, M.M. and Harrigan, P. (2014) 'CRM to social CRM: the integration of new technologies into customer relationship management', Journal of Strategic Marketing, Vol. 22, No. 2, pp.149-176.

Collective Intellect (2010) Strategy for Social CRM, White Paper.

Deng, S. and Dart, J. (1994) 'Measuring market orientation: a multi-factor, multi-item approach', Journal of Marketing Management, Vol. 10, No. 8, pp.725-742.

Elena, C.A. (2016) 'Social media - a strategy in developing customer relationship management', 3rd Global Conference on Business, Economics, Management and Tourism, Rome, Italy.

Greenberg, P. (2009) Social CRM Comes of Age, Oracle [online] http://hosteddocs.ittoolbox.com/social-crm-comes-of-age_paul-green.

Greenberg, P. (2010) 'The impact of CRM 2.0 on customer insight', Journal of Business \& Industrial Marketing, Vol. 25, No. 6, pp.410-419.

Jais, S-D. (2007) 'Structural equation modeling', in The Successful Use of Information in Multinational Companies, pp.132-135, Deutscher Universitäts-Verlag, GWV Fachverlage $\mathrm{GmbH}$, Wiesbaden.

Kamboj, S. et al. (2016) 'Impact of social CRM capabilities on firm performance: examining the mediating role of co-created customer experience', International Journal of Information Systems in the Service Sector, Vol. 8, No. 4, pp.1-16.

Kang, J. and Kim, J. (2017) 'Online customer relationship marketing tactics through social media and perceived customer retention orientation of the green retailer', Journal of Fashion Marketing and Management: An International Journal, Vol. 21, No. 3, pp.298-316.

Kaplan, A.M. and Haenlein, M. (2010) 'Users of the world, unite! The challenges and opportunities of social media', Business Horizon, Vol. 53, No. 1, pp.59-68.

Kohli, A.K. and Jaworski, B.J. (1990) 'Market orientation: the construct, research propositions, and managerial implications', Journal of Marketing, Vol. 54, No. 2, pp.1-18. 
Kubina, M. and Lendel, V. (2014) 'Successful application of social CRM in the company', 2nd Global Conference on Business, Economics, Management and Tourism, Prague, Czech Republic.

Kulkarni, P. and Gnanpragash, J. (2017) Assessing the Impact of Social CRM Strategies Adopted by Snapdeal, An Indian E-tailer, Unpublished [online] https://doi.org/10.13140 /rg.2.2.33032.72961 (accessed 12 October 2017).

Küpper et al. (2014) 'Performance measures for social CRM: a literature review', 16th International Conference on Enterprise Information Systems (ICEIS).

Malthouse, E.C. et al. (2013) 'Managing customer relationships in the social media era: introducing the social CRM house', Journal of Interactive Marketing, Vol. 27, No. 4, pp.270-280.

Malthouse, E.C. et al. (2013) 'Managing customer relationships in the social media era: introducing the social CRM house', Journal of Interactive Marketing, Vol. 27, No. 4, pp.270-280.

Metz, A. (2011) The Social Customer: 'How Brands Can Use Social CRM to Acquire, Monetize, and Retain Fans, Friends, and Followers, McGraw-Hill, USA.

Narver, C.J., Slater, F.S. and Tietje, B. (1998) 'Creating a market orientation', Journal of Market Focused Management, September, Vol. 2, No. 3, pp.241-255.

Narver, J.C. and Slater, S.F. (1990) 'The effect of a market orientation on business profitability', Journal of Marketing, Vol. 54, pp.20-35.

Paliouras, K. and Siakas, K. (2017) 'Social customer relationship management: a case study', International Journal of Entrepreneurial Knowledge, Vol. 5, No. 1, pp.20-34, https://doi:10.1515/ijek-2017-0002 (accessed 11 October 2017).

Palmatier, R.W., Dant, R.P., Grewal, D. and Evans, K.R. (2006) 'Factors influencing the effectiveness of relationship marketing', Journal of Marketing, October, Vol. 70, No. 4, pp.136-153.

Patil, M.Y. (2015) 'Social media and customer relationship management', OSR Journal of Business and Management (IOSR-JBM) 2015: Proceedings of the 2nd National Conference on Value Based Management - Business for Value or Values in Business, pp.27-32, Institute Of Management MET-Bhujbal Knowledge City.

Payne, A. and Frow, P. (2005) 'A strategic framework for customer relationship management', Journal of Marketing, Vol. 69, No. 4, p.167.

Reinhold, O. and Alt, R. (2012a) 'Analytical social CRM: concept and tool support', 24th Bled e Conference e Future: Creating Solutions for the Individual, Organizations and Society, 12-15 June 2011, Bled, Slovenia.

Reinhold, O. and Alt, R. (2012b) 'Social customer relationship management: state of the art and learnings from current projects', in 25th Bled e Conference e Dependability: Reliable and Trustworthy e Structures, e Processes, e Operations and e-Services for the Future, 17 June-20 June, Bled, Slovenia.

Rodriguez, M., Peterson, R.M. and Ajjan, H. (2014) 'Crm/social media technology: impact on customer orientation process and organizational sales performance', in Kubacki, K. (Ed.): Ideas in Marketing: Finding the New and Polishing the Old Developments in Marketing Science: Proceedings of the Academy of Marketing Science, Springer, Cham.

Roggeveen, A.L. and Grewal, D. (2016) 'Editorial', Journal of Consumer Marketing, Vol. 33, No. 2.

Roggeveen, A.L. and Grewal, D. (2016) 'Editorial', Journal of Consumer Marketing, Vol. 33, No. 2 [online] https://doi.org/10.1108/JCM-12-2015-1649.

Sarner, A. (2012) Social CRM Means Business in 2012, Forbes.

Sarner, A. et al. (2010) Top Use Cases and Benefits for Successful Social CRM, Gartner [online] http://img2.insight.com/graphics/fr/adobe/insight_article13.pdf. 
Sarner, A. et al. (2011) Magic Quadrant for Social CRM, Gartner [online] https://www.gartner.com/doc/2179417.

Shyamalee, S. and Srinath, P. (2010) 'Social CRM - Dealing with the change within', Infosys, Bangalore.

Song, M. et al. (2017) 'Statistics-based CRM approach via time series segmenting RFM on large scale data', Knowledge-Based Systems, Vol. 132, pp.21-29.

Trainor, K.J., Andzulis, J.M., Rapp, A. and Agnihotri, R. (2014) 'Social media technology usage and customer relationship performance: a capabilities-based examination of social CRM', Journal of Business Research, Vol. 67, No. 6, pp.1201-1208.

Vargo, S.L. and Lusch, R.F. (2016) 'Institutions and axioms: an extension and update of service-dominant logic', Journal of the Academy of Marketing Science, Vol. 44, No. 1, pp.5-23.

Wagner, T.R. and Hughes, J. (2010) Social CRM: The New Frontier of Marketing, Sales and Service, Accenture, Dublin [online] http://www.accenture.com/SiteCollectionDocuments/ PDF/SocialCRMResearch.pdf.

Wang, R. and Owyang, J. (2010) Social CRM: The New Rules of Relationship Management.

Wang, Z. and Kim, H.G. (2017) 'Can social media marketing improve customer relationship capabilities and firm performance? Dynamic capability perspective', Journal of Interactive Marketing, Vol. 39, pp.15-26.

Woodcock, N., Green, A. and Starkey, M. (2011) 'Social CRM as a business strategy', Journal of Database Marketing \& Customer Strategy Management, March, Vol. 18, No. 1, pp.50-64.

Zahoor, S.Z. et al. (2016) 'Social media and CRM 2.0: a conceptual framework for analysis', International Journal of Social Science \& Interdisciplinary Research, Vol. 5, No. 4, pp.25-37. 


\section{Appendix A}

Table related to correlation (Hypothesis 2)

Table A1 Correlation between social CRM duration and operative factors

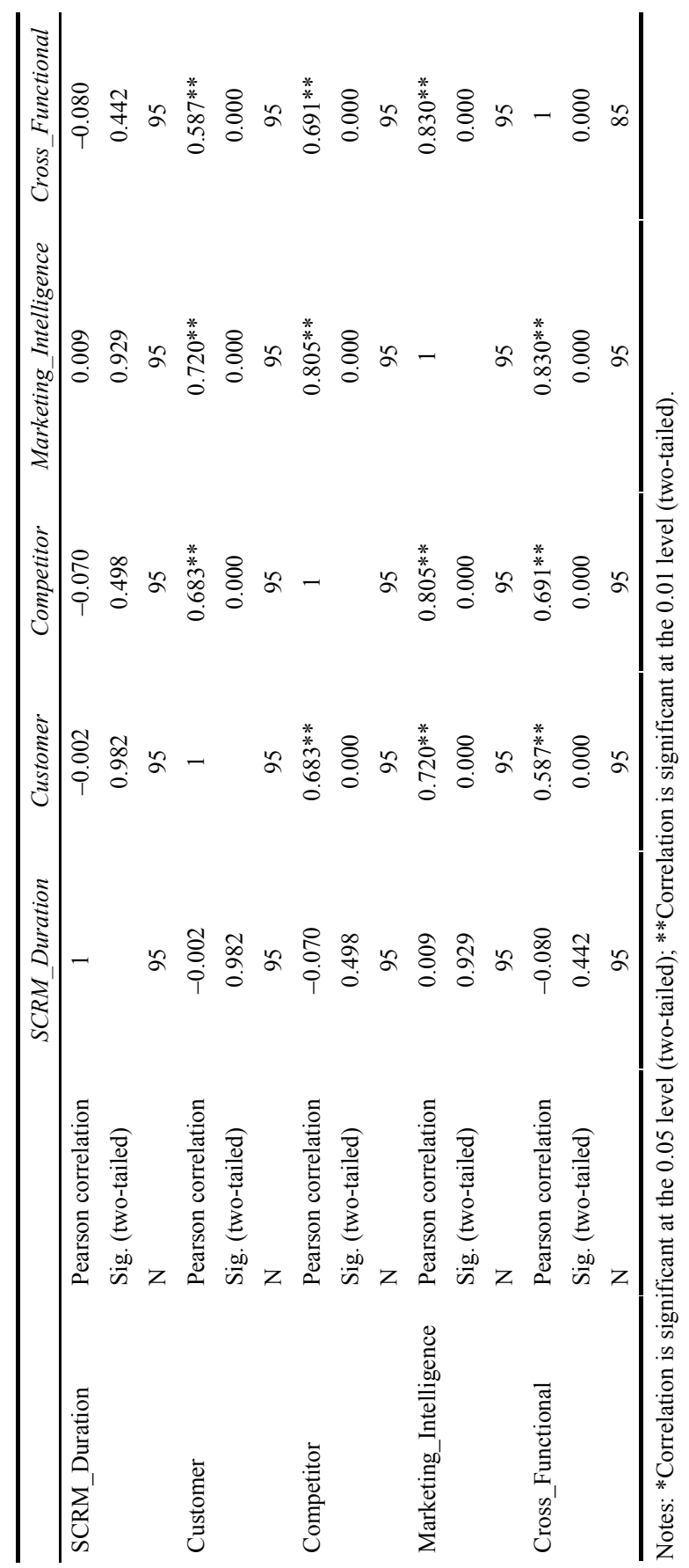




\section{Appendix B}

Table related to correlation (Hypothesis 3)

Table B1 Correlation between number of functions for which social CRM is used and operative factors

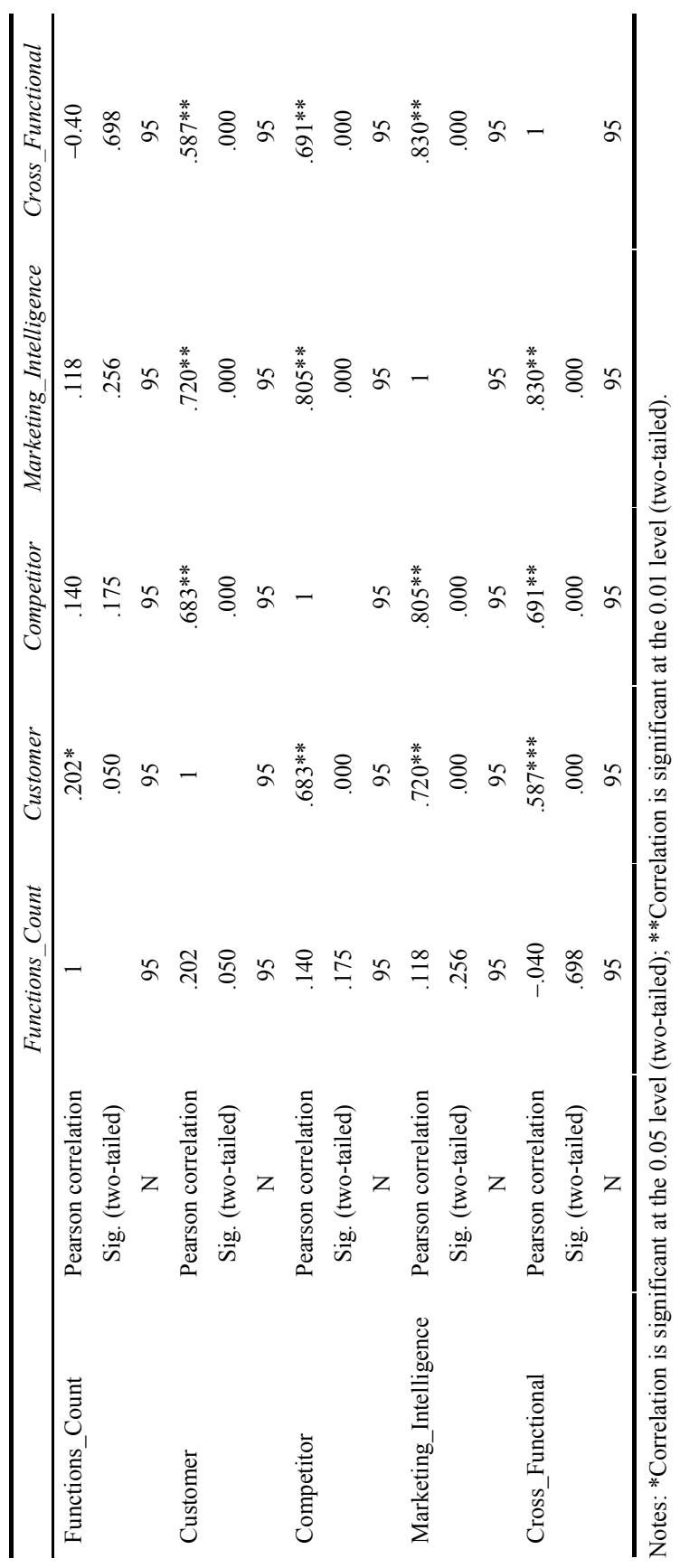




\section{Appendix C}

Tables related to correlation and regression analysis (Hypothesis 4)

Table C1 Pearson correlations coefficients

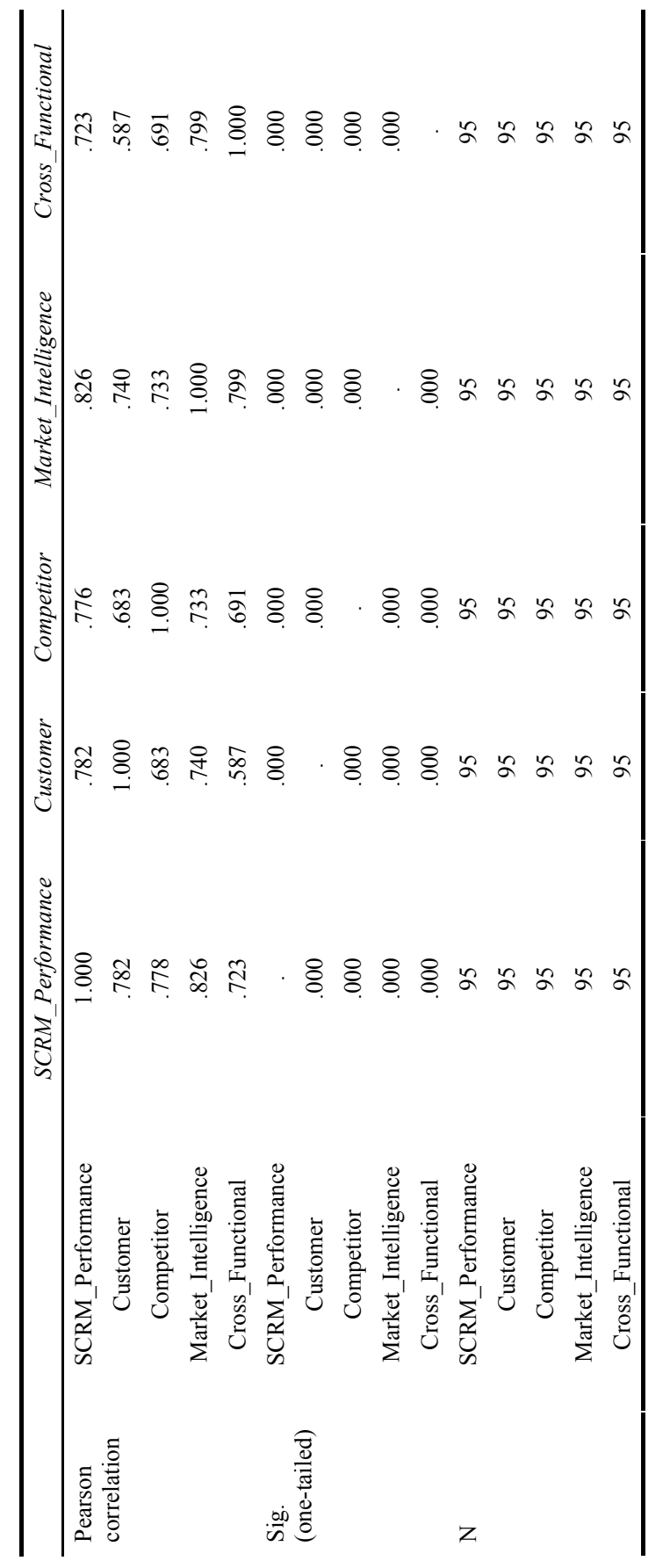


Figure 9 Correlation analysis of customer and SCRM_Performance

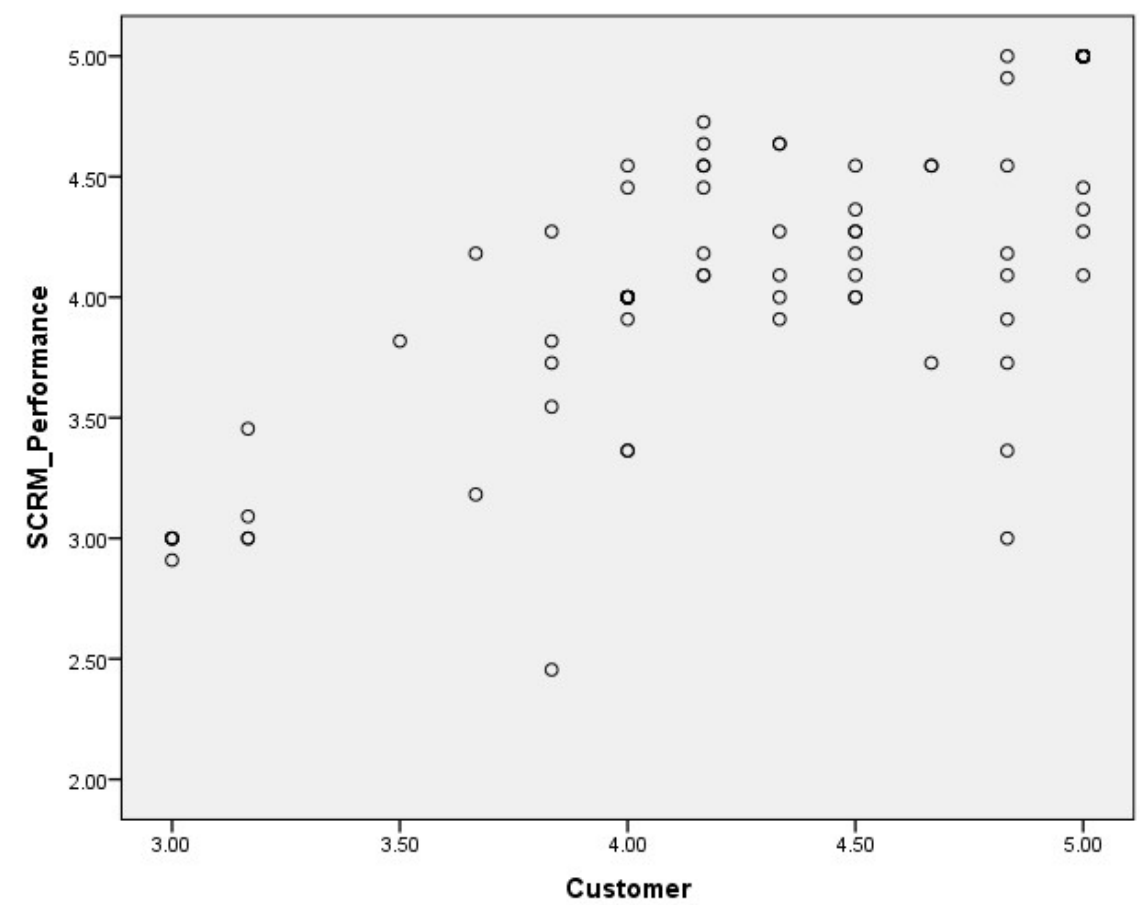

Figure 10 Correlation analysis of competitor and SCRM_Performance

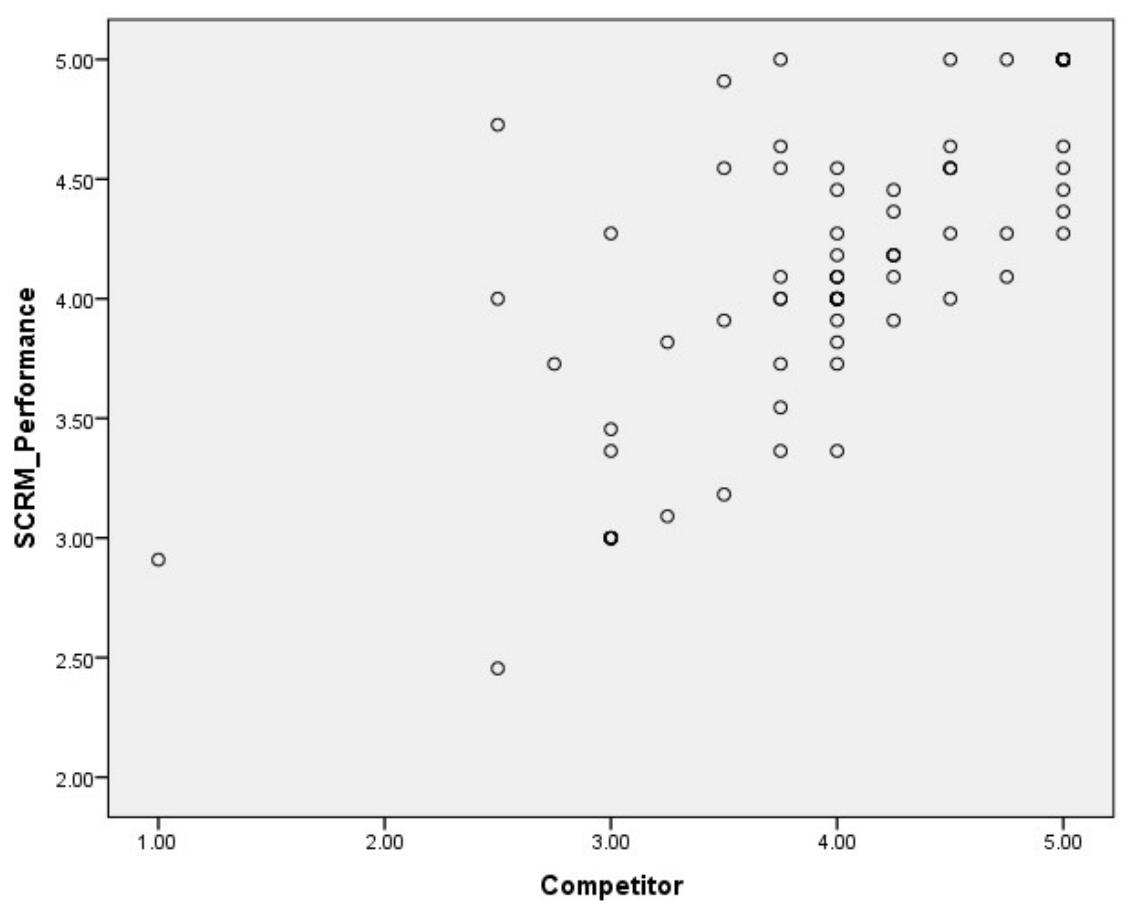


Figure 11 Correlation analysis of Market_Intelligence and SCRM_Performance

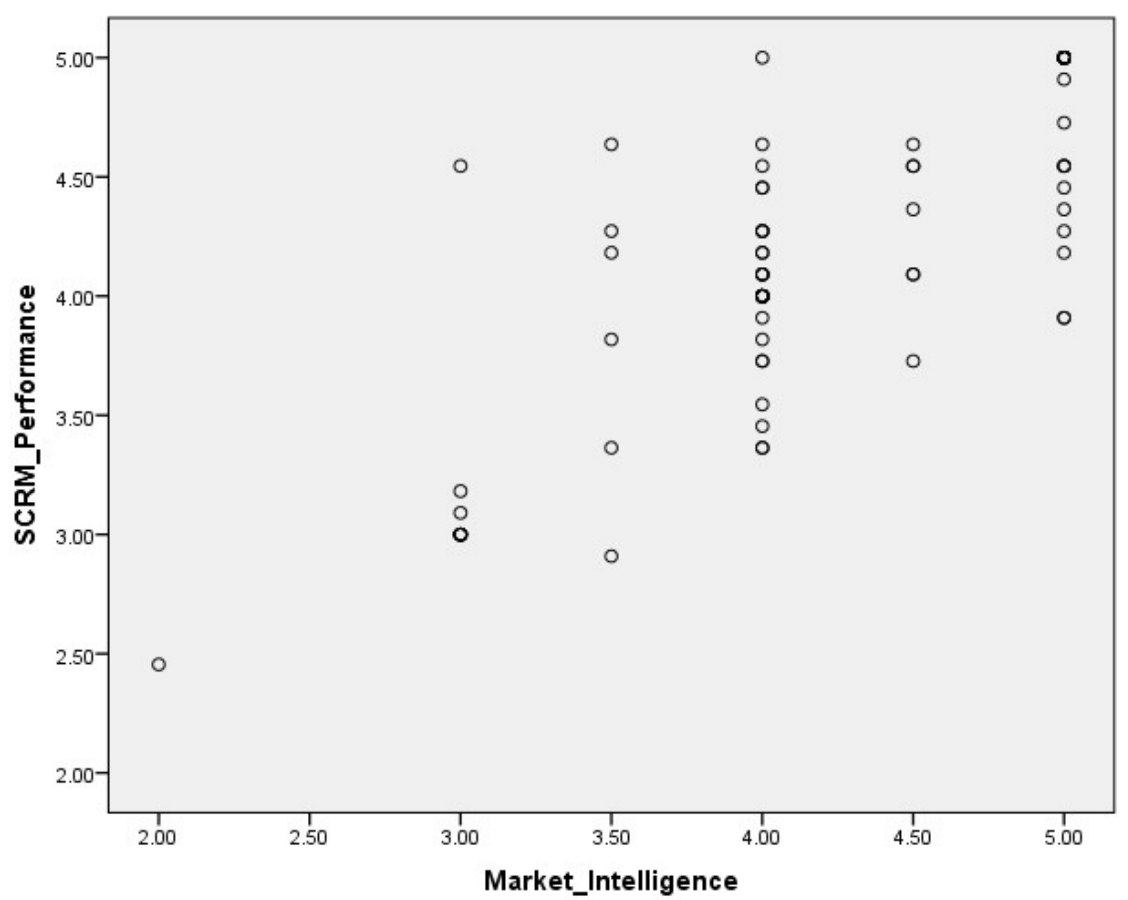

Table C2 Model summary ${ }^{\mathrm{b}}$

\begin{tabular}{|c|c|c|c|c|c|c|c|c|c|c|}
\hline \multirow[b]{2}{*}{ Model } & \multirow[b]{2}{*}{$R$} & \multirow[b]{2}{*}{$\begin{array}{c}R \\
\text { square }\end{array}$} & \multirow[b]{2}{*}{$\begin{array}{l}\text { Adjusted } \\
R \text { square }\end{array}$} & \multirow{2}{*}{$\begin{array}{c}\text { Std. } \\
\text { error of } \\
\text { the } \\
\text { estimate }\end{array}$} & \multicolumn{5}{|c|}{ Change statistics } & \multirow[b]{2}{*}{$\begin{array}{l}\text { Durbin- } \\
\text { Watson }\end{array}$} \\
\hline & & & & & $\begin{array}{l}\text { R square } \\
\text { change }\end{array}$ & $\begin{array}{c}F \\
\text { change }\end{array}$ & $d f 1$ & $d f 2$ & $\begin{array}{c}\text { Sig, F } \\
\text { change }\end{array}$ & \\
\hline 1 & $.886^{\mathrm{a}}$ & .784 & .775 & .31128 & .784 & 81.722 & 4 & 90 & .000 & 1.604 \\
\hline
\end{tabular}

Notes: ${ }^{a}$ Predictors: (constant), Cross_Fumctional, customer, competitor,

Market Intelligence.

${ }^{\mathrm{b}}$ Dependent variable: SCRM_Performance.

Table C3 ANOVA a analysis

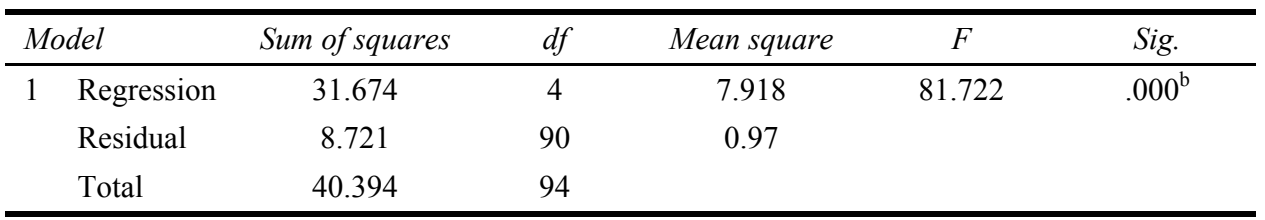

Notes: ${ }^{a}$ Dependent variable: SCRM_Performance.

${ }^{\mathrm{b}}$ Predictors: (constant), Cross Fumctional, customer, competitor,

Market_Intelligence. 
Table C4 Model coefficients ${ }^{\mathrm{a}}$

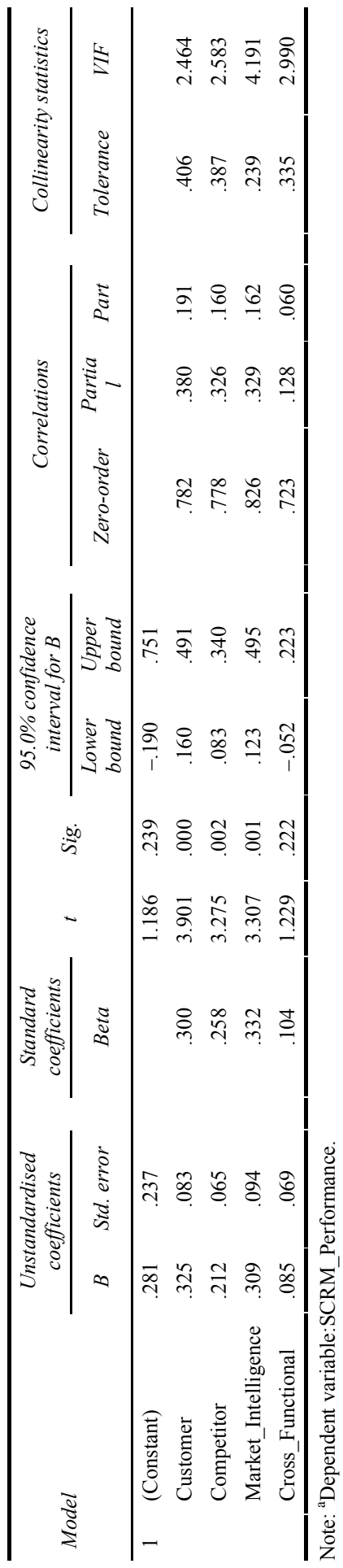


Figure 12 Correlation analysis of Cross_Functional and SCRM_Performance

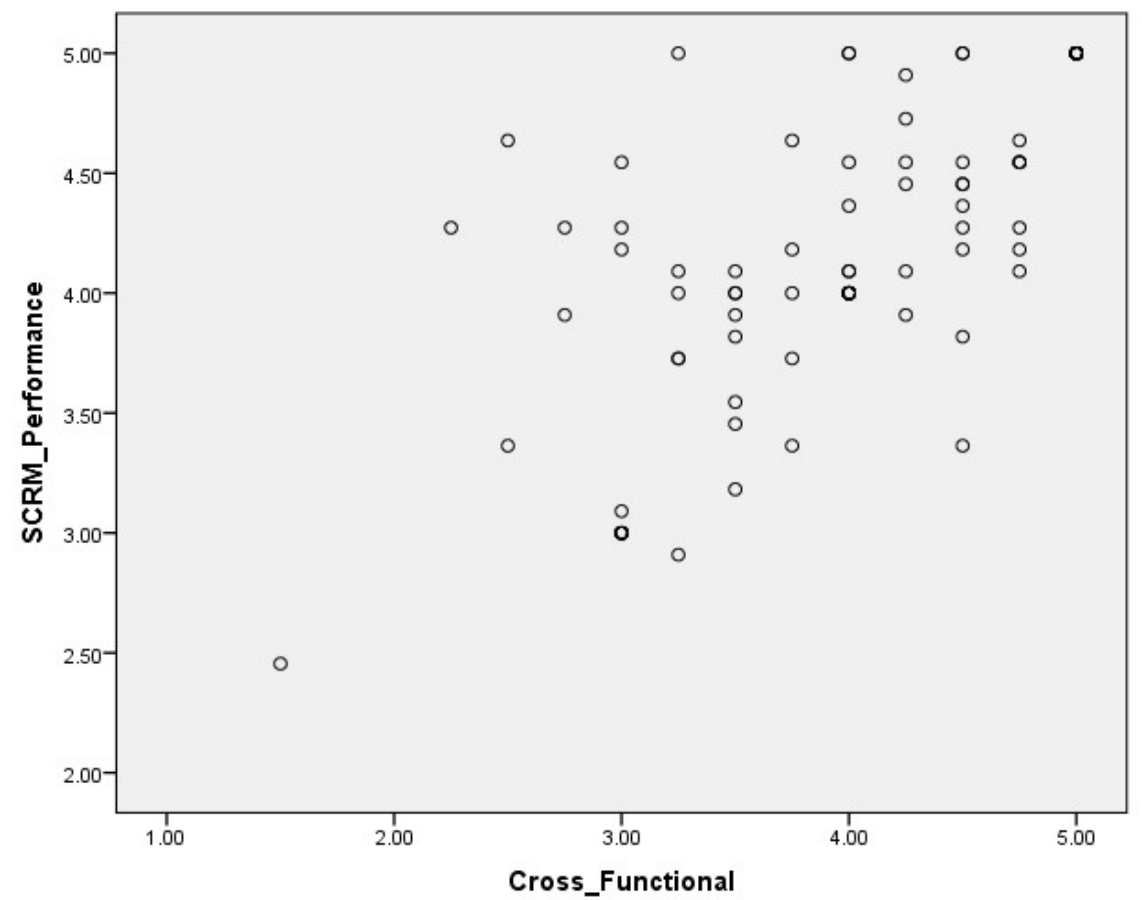

\section{Appendix D}

Table related to chi-square analysis (Hypothesis 5)

Table D1 Chi-square analysis

\begin{tabular}{lccc}
\hline & Value & $d f$ & Asymp. sig. (two-sided) \\
\hline Pearson chi-square & $1.237^{\mathrm{a}}$ & 4 & .872 \\
Likelihood ratio & 1.894 & 4 & .755 \\
N of valid cases & 95 & & \\
\hline
\end{tabular}

Notes: ${ }^{\mathrm{a}}$ Four cells $(40.0 \%)$ have expected count less than 5 . The minimum expected count is .72 . 


\section{Appendix E}

\section{Goodness of fit statistics}

\begin{tabular}{|c|c|}
\hline Degrees of freedom for $(\mathrm{C} 1)-(\mathrm{C} 2)$ & 94 \\
\hline Maximum likelihood ratio chi-square (C1) & $554.090(P=0.0000)$ \\
\hline Browne's (1984) ADF chi-square (C2_NT) & $338.409(P=0.0000)$ \\
\hline Estimated non-centrality parameter (NCP) & 0.93 \\
\hline $90 \%$ confidence interval for NCP & $(0.0 ; 14.21)$ \\
\hline Minimum fit function value & 0.14 \\
\hline Population discrepancy function value (FO) & 0.0094 \\
\hline $90 \%$ confidence interval for F0 & $(0.0 ; 0.14)$ \\
\hline $\begin{array}{l}\text { Root mean square error of approximation } \\
\text { (RMSEA) }\end{array}$ & 0.026 \\
\hline $90 \%$ confidence interval for RMSEA & $(0.0 ; 0.11)$ \\
\hline $\begin{array}{l}\text { P-value for test of close fit } \\
\text { (RMSEA }<0.05)\end{array}$ & 0.60 \\
\hline Expected cross-validation index (ECVI) & 0.44 \\
\hline $90 \%$ confidence interval for ECVI & $(0.43 ; 0.58)$ \\
\hline ECVI for saturated model & 0.57 \\
\hline ECVI for independence model & 6.53 \\
\hline Chi-square for independence model (120 df) & 2238.933 \\
\hline Normed fit index (NFI) & 0.98 \\
\hline Non-normed fit index (NNFI) & 1.00 \\
\hline Parsimony normed fit index (PNFI) & 0.61 \\
\hline Comparative fit index (CFI) & 1.00 \\
\hline Incremental fit index (IFI) & 1.00 \\
\hline Relative fit index (RFI) & 0.96 \\
\hline Critical N (CN) & 23.084 \\
\hline Root mean square residual (RMR) & 0.030 \\
\hline Standardised RMR & 0.034 \\
\hline Goodness of fit index (GFI) & 0.96 \\
\hline Adjusted goodness of fit index (AGFI) & 0.92 \\
\hline Parsimony goodness of fit index (PGFI) & 0.480 \\
\hline
\end{tabular}

